\title{
Regulation of Hypothalamic Signaling by Tuberoinfundibular Peptide of 39 Residues Is Critical for the Response to Cold: A Novel Peptidergic Mechanism of Thermoregulation
}

\author{
Eugene L. Dimitrov, Yoon Yi Kim, and Ted B. Usdin \\ Section On Fundamental Neuroscience, National Institute Of Mental Health, National Institutes Of Health, Bethesda, Maryland 20892
}

Euthermia is critical for mammalian homeostasis. Circuits within the preoptic hypothalamus regulate temperature, with fine control exerted via descending GABAergic inhibition of presympathetic motor neurons that control brown adipose tissue (BAT) thermogenesis and cutaneous vascular tone. The thermoregulatory role of hypothalamic excitatory neurons is less clear. Here we report peptidergic regulation of preoptic glutamatergic neurons that contributes to temperature regulation. Tuberoinfundibular peptide of 39 residues (TIP39) is a ligand for the parathyroid hormone 2 receptor (PTH2R). Both peptide and receptor are abundant in the preoptic hypothalamus. Based on PTH2R and vesicular glutamate transporter 2 (VGlut2) immunolabeling in animals with retrograde tracer injection, PTH2R-containing glutamatergic fibers are presynaptic to neurons projecting from the median preoptic nucleus (MnP0) to the dorsomedial hypothalamus. Transneuronal retrograde pathway tracing with pseudorabies virus revealed connectivity between MnP0 VGlut2 and PTH2R neurons and BAT. MnPO injection of TIP39 increased body temperature by $2^{\circ} \mathrm{C}$ for several hours. Mice lacking TIP39 signaling, either because of PTH2R-null mutation or brain delivery of a PTH2R antagonist had impaired heat production upon cold exposure, but no change in basal temperature and no impairment in response to a hot environment. Thus, TIP39 appears to act on PTH2Rs present on MnPO glutamatergic terminals to regulate their activation of projection neurons and subsequent sympathetic BAT activation. This excitatory mechanism of heat production appears to be activated on demand, during cold exposure, and parallels the tonic inhibitory GABAergic control of body temperature.

\section{Introduction}

Mammals achieve euthermia by hypothalamic control of heat production and dissipation. Warm-sensitive preoptic area neurons tonically inhibit neighboring cold-sensitive cells and send an inhibitory signal to the dorsomedial hypothalamus (DMH) or directly to the medullary rostral raphe pallidus (Boulant and Silva, 1988; Osaka, 2004; Nakamura et al., 2009; Tanaka et al., 2009; Yoshida et al., 2009). These GABAergic neurons control heat production and dissipation by regulating premotor sympathetic neurons connected to brown adipose tissue (BAT) (Nakamura and Morrison, 2008) or cutaneous blood vessels (Tanaka et al., 2009). The projections and transmitter content of coldsensitive neurons that stimulate heat production and conservation are still not well defined. Cold exposure activates numerous preoptic neurons (Baffi and Palkovits, 2000; Bratincsák and

\footnotetext{
Received May 26, 2011; revised 0ct. 27, 2011; accepted 0ct. 31, 2011.

Author contributions: E.L.D. and T.B.U. designed research; E.L.D. and Y.Y.K. performed research; E.L.D. and T.B.U. analyzed data; E.L.D. and T.B.U. wrote the paper.

This work was supported by the Intramural Program of the National Institute of Mental Health, NIH. We appreciate the help and support provided by Milan Rusnak and Jonathan Kuo. Viruses were obtained through the Center for Neuroanatomy with Neurotropic Viruses.

The authors declare no competing financial interests.

Correspondence should be addressed to Ted B. Usdin, Section on Fundamental Neuroscience, National Institute of Mental Health, National Institutes of Health, Bldg 35, Room 1B-215, 35 Convent Drive, Bethesda, MD 20892. E-mail: usdint@mail.nih.gov.

DOI:10.1523/JNEUROSCI.2619-11.2011

Copyright $\odot 2011$ the authors $\quad 0270-6474 / 11 / 3118166-14 \$ 15.00 / 0$
}

Palkovits, 2004), including BAT projecting cells (Cano et al., 2003). Glutamatergic transmission clearly plays a part in hypothalamic thermoregulation since anterior hypothalamic glutamate injection activates BAT sympathetic input, stimulating thermogenesis (Yoshimatsu et al., 1993; Nakamura and Morrison, 2008). Parabrachial nucleus projections to the hypothalamus are glutamatergic and preoptic thermoregulatory glutamatergic interneurons are proposed (Morrison and Nakamura, 2011) but little is known about their connectivity or function. Stimulation of heat production via histamine-sensitive glutamatergic hypothalamic efferents has also been recently proposed (Lundius et al., 2010).

Tuberoinfundibular peptide of 39 residues (TIP39) is synthesized by posterior thalamic subparafascicular area neurons that project to the hypothalamic paraventricular, arcuate and dorsomedial nuclei and preoptic region (Dobolyi et al., 2003a,b) where TIP39's receptor, the parathyroid hormone 2 receptor (PTH2R), has a closely matching distribution (Usdin et al., 1999a; Faber et al., 2007; for review, see Dobolyi et al., 2010). Near the paraventricular nucleus, where it has been examined most closely, PTH2Rs are present on glutamatergic terminals (Dobolyi et al., 2006; Dimitrov and Usdin, 2010). PTH2R activation increases cAMP, and cytoplasmic $\mathrm{Ca}^{2+}$ in some cells, so it may facilitate nerve terminal neurotransmitter release (Usdin et al., 2002). We recently found that TIP39 activates neuroendocrine cells in a glutamate-dependent manner (Dimitrov and Usdin, 2010). Based on TIP39 and PTH2R presence throughout the preoptic region and DMH (Dobolyi et al., 2003a,b, 2006; Faber et al., 

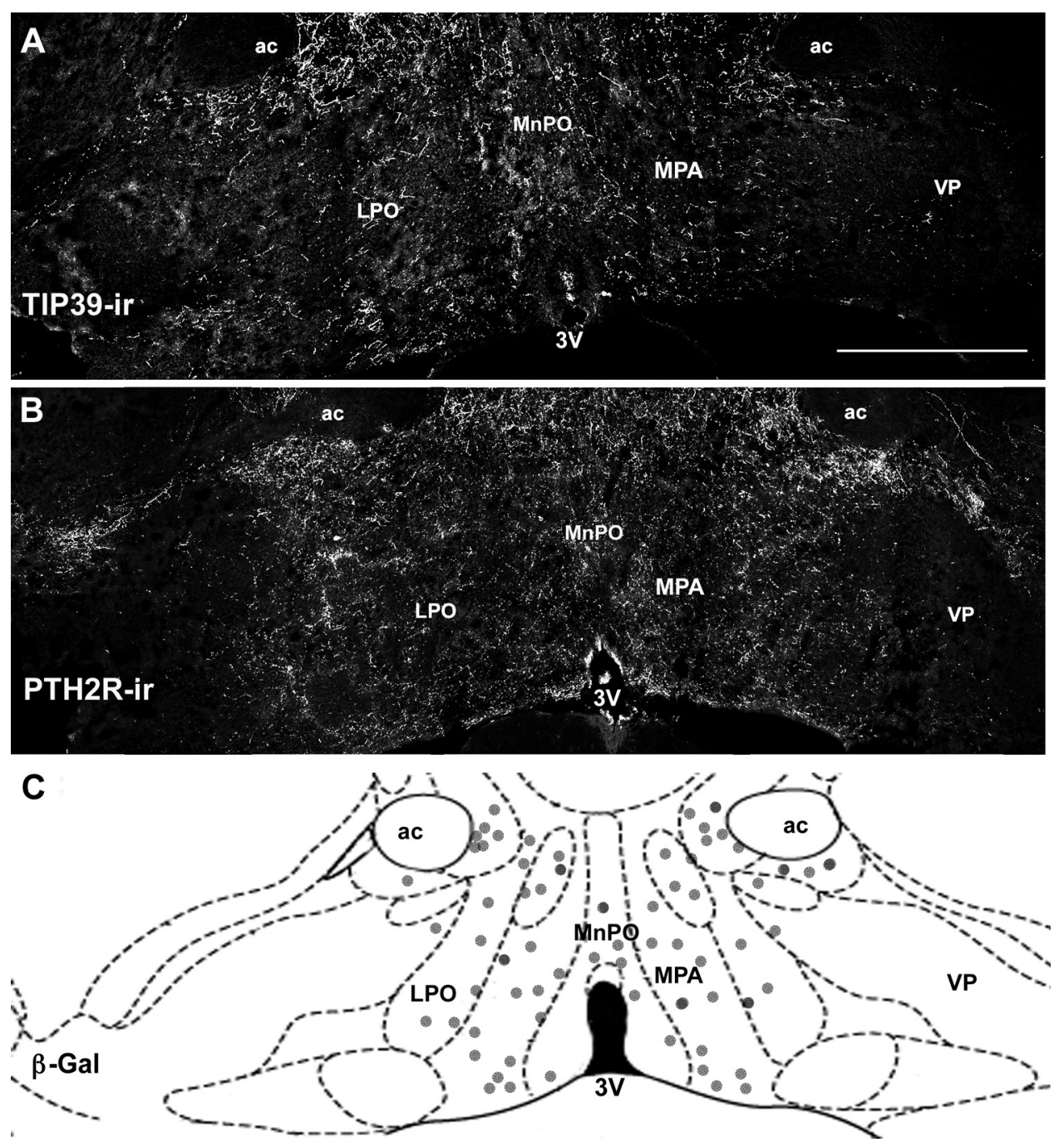

Figure 1. Expression of TIP39 and PTH2R immunoreactivity in the preoptic hypothalamus. $\boldsymbol{A}, \boldsymbol{B}$, Low-magnification images show TIP39-ir $(\boldsymbol{A})$ and PTH2R-ir $(\boldsymbol{B})$ concentrated in hypothalamic preoptic areas. C, Schematic representation of the preoptic hypothalamus at the same level shows the location of $\beta$-gal-expressing cells in a PTH2R- $\beta$-gal knock-in mouse. Scale bar (in $A$ ) $\boldsymbol{A}, \boldsymbol{B}, 500$ $\mu \mathrm{m}$. 3V, Third ventricle; ac, anterior commissure; LPO, lateral preoptic area; VP, ventral pallidus.

2007) we have now examined their role in thermoregulation, with the hypothesis that it might occur through modulation of glutamatergic function.

First, to test whether median preoptic nucleus (MnPO) PTH2R-expressing cells are part of a thermoregulatory circuit, we used retrograde tracing from the DMH and BAT in combination with immunohistochemistry and transgenic mice with celltype markers to address potential connectivity between $\mathrm{MnPO}$ PTH2R neurons and thermoregulatory pathways. Next, we investigated effects of PTH2R activation on body temperature, using PTH2R knock-out mice to confirm the specificity of TIP39's effect. Finally, to help identify functions of endogenous TIP39 we compared responses to environmental temperature perturbation between mice with and without TIP39 signaling. It appears that TIP39 potently stimulates thermogenesis via PTH2Rs on MnPO glutamatergic terminals that may activate a glutamatergic pathway from the preoptic hypothalamus to sympathetic premotor centers that innervate BAT.

\section{Materials and Methods}

Animals. All procedures were approved by the National Institute of Mental Health Animal Care and Use Committee and were in accordance with the Institute for Laboratory Animal Research Guide for the Care and Use of Laboratory Animals. Mice were housed under a $12 \mathrm{~h}$ light/dark cycle (lights on at 6:00 A.M.) with ad libitum access to food and water. Male mice between 80 and $140 \mathrm{~d}$ of age and weighing from 28 to $32 \mathrm{~g}$ were used for all experiments and were singly housed starting at least 1 week before all temperature experiments. C57BL/6J mice used for $\mathrm{MnPO}$ and $\mathrm{DMH}$ cannulation and TIP39 injection experiments were obtained from Jackson Laboratories. Wild-type and knock-out $(\mathrm{KO})$ mice from the same Het $\times$ Het breedings of a PTH2R-KO line were used in all other temperature experiments. The development and genotyping of PTH2R-KO mice were previously described (Dimitrov and Usdin, 2010). Each mouse was used in not more than two different experiments with at least $7 \mathrm{~d}$ elapsing between the experiments. Testing was initiated at 8:00 A.M. with at least $1 \mathrm{~h}$ for the animal's acclimatization to one of the two rooms used for testing. Neuroanatomical experiments were performed using wildtype mice or lines with gene-specific markers. A line with lacZ (encoding $\beta$-galactosidase; $\beta$-gal) replacing exon 1 of the PTH2R (PTH2R- $\beta$-gal), which marks PTH2R-expressing neurons, has been previously described (Faber et al., 2007). Transgenic mice with green fluorescent protein (GFP) sequence introduced into the VGlut2 gene of a bacterial artificial chromosome (VGlut2-GFP BAC) were generated by embryo injection in the NIMH intramural transgenic core facility of a BAC (RP23-84M15, Children's Hospital Oakland Research Institute, Oakland CA) produced 

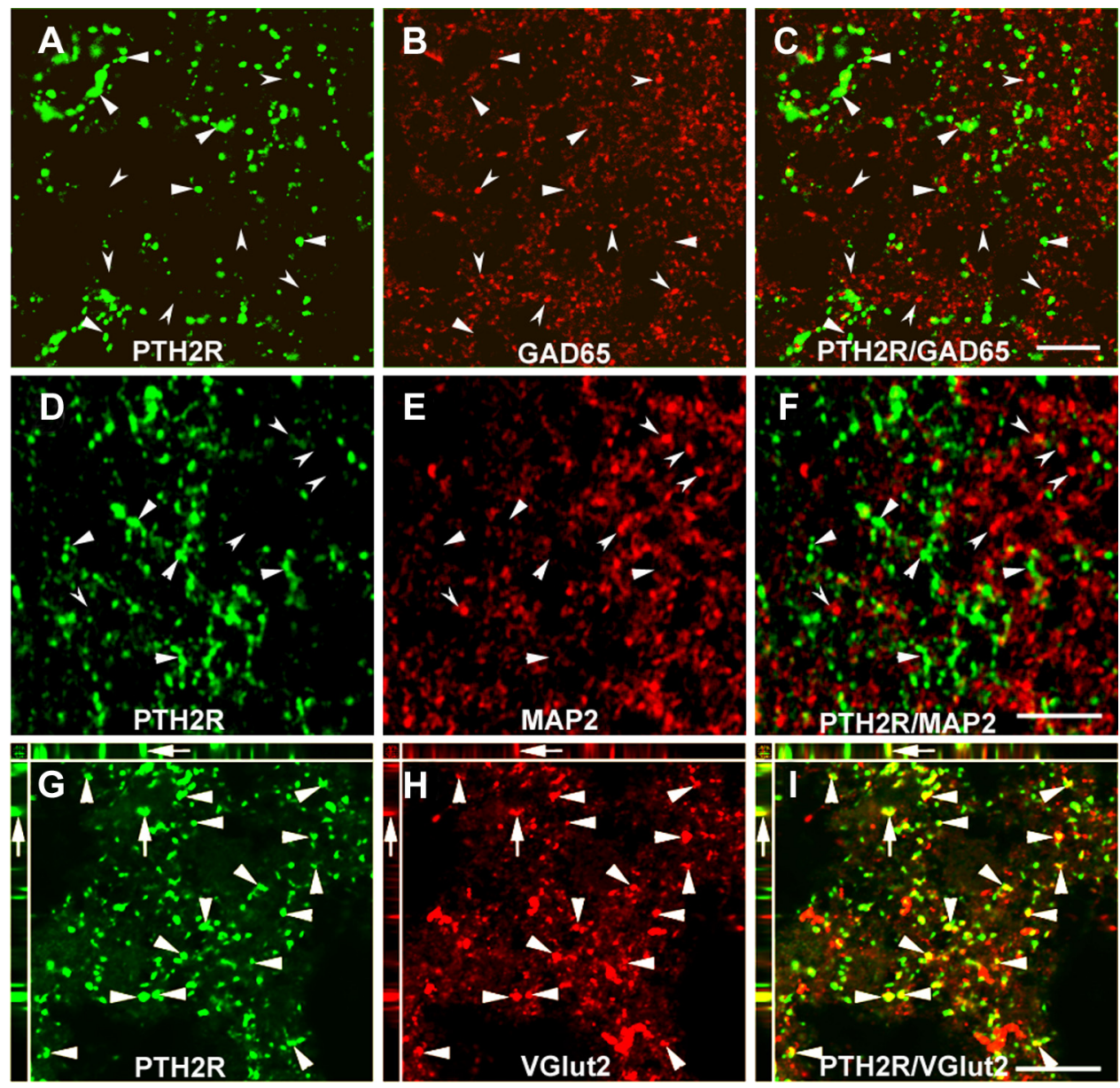

Figure 2. PTH2R and VGlut2 immunoreactivity overlap in the MnP0.PTH2R-ir ( $\boldsymbol{A}, \boldsymbol{D}$, and $\boldsymbol{G}), G A D 65$-ir $(\boldsymbol{B}), \mathrm{MAP2}$-ir $(\boldsymbol{E})$, and VGlut2-ir $(\boldsymbol{H})$ are shown as single channels and as merged images ( $\boldsymbol{C}, \boldsymbol{F}$, and $\boldsymbol{I}$ ). There is no apparent colocalization of PTH2R-ir with GAD65-ir or MAP2-ir, a dendritic marker. $\boldsymbol{A}-\boldsymbol{F}$, Examples of puncta labeled only with the PTH2R antibody are indicated by arrowheads and ones labeled by the GAD65 or MAP2 antibodies are indicated by indented arrowheads. Images are confocal microscope single optical sections. G-I, The images are from a Z-series spanning $\sim 1.2$ $\mu \mathrm{m}$. The labeled structure indicated by the arrow is present in the selected $X-Z$ (left of each panel) and $Y-Z$ (top of each panel) planes. Arrowheads point to other puncta coexpressing the two markers (yellow). Scale bars, $10 \mu \mathrm{m}$

by the GENSAT project (Gong et al., 2003). The pattern of GFP expression was detected by labeling brain sections with an antibody to GFP and a line identified with an expression pattern in the anterior hypothalamus similar to that shown for vesicular glutamate transporter 2 (VGlut2) by in situ hybridization studies (Lin et al., 2003).

Implantation of thermosensitive transponders. Thermosensitive transponders (model IPTT-300, BioMedic Data Systems) were subcutaneously inserted into the interscapular region using the supplied trochar injection device to pierce the skin midway between the fore- and hindlimbs, as recommended by the supplier. Due to the small trochar tip, no wound closure was required. Animals were used for temperature experiments starting 5-7 d following transponder insertion.

CNS drug administration. For MnPO microinjection a 26-gauge stainless steel guide cannula (Plastics One) was implanted into the anterior hypothalamus and secured to the skull with three screws and acrylic dental cement of isoflurane anesthetized animals held in a stereotaxic apparatus. Coordinates were: anteroposterior $+0.4 \mathrm{~mm}$, lateral $0.0 \mathrm{~mm}$, and dorsoventral $-4.0 \mathrm{~mm}$ from bregma. Stylets were placed in each cannula to maintain patency. Animals were handled daily and the stylets manipulated to acclimate the animals to the microinjection procedure and reduce tissue growth on the cannulae tips. The same technique was used for DMH (anteroposterior $-1.8 \mathrm{~mm}$, lateral $0.2 \mathrm{~mm}$, and dorsoventral $-4.5 \mathrm{~mm}$ ) and left lateral ventricle (anteroposterior $-0.6 \mathrm{~mm}$, lateral $+1.2 \mathrm{~mm}$, and dorsoventral $-2.0 \mathrm{~mm}$ from bregma) cannulation. On the day of the experiment, after $1 \mathrm{~h}$ acclimation to the procedure room, a 33-gauge internal injector with a $0.5 \mathrm{~mm}$ projection was inserted into the cannula and $0.1 \mu \mathrm{l}$ of vehicle containing $0.1 \%$ bovine serum albumin (Equitech-Bio Inc.) in saline or 50, 100, and 200 pmol of TIP39 was delivered over $5 \mathrm{~min}$. The lateral ventricle injections were performed in the same way with a dose of 500 pmol of TIP39 or $\mathrm{H}^{3} \mathrm{Y}^{4} \mathrm{~W}^{5} \mathrm{H}^{6}$-TIP39 (HYWH, a PTH2R antagonist; Kuo and Usdin, 2007) in $0.5 \mu$ l of vehicle. The injectors were removed $1 \mathrm{~min}$ after completion of the injection and the animal's body temperature was monitored for 7-8 h. All injections were performed at room temperature $\left(19.8-23^{\circ} \mathrm{C}\right)$ and the animals were held in their home cages at room temperature unless placed in a modified environment as specifically indicated for particular experiments. In all intracranial injection experiments cannula placement was evaluated by fixing and sectioning the brain after the experiment, and only data from animals with appropriate cannula placement were used. TIP39 and HYWH were dissolved and diluted in $10 \mathrm{~mm}$ Tris $\mathrm{HCl}, 6 \% \mathrm{DMSO}$, at $\mathrm{pH}$ 7.0. Both peptides were synthesized by Midwest Biomedical Resources. Nadolol (Sigma-Aldrich) and norepinephrine (Arterenol, Sigma-Aldrich) were dissolved in saline and injected intraperitoneally at $20 \mathrm{mg} / \mathrm{kg}$ for nadolol and $1 \mathrm{mg} / \mathrm{kg}$ for norepinephrine.

Retrograde tracers. A stereotaxic surgical procedure similar to that described for CNS cannulations was used to inject $0.1 \mu \mathrm{l}$ of Fluoro-Gold (FG; hydroxystilbamidine, Invitrogen) or rhodamine latex beads (red Retrobeads; Lumafluor) into the DMH. The solutions of $2.0 \%$ FG or rhodamine beads in saline were delivered via a 34 gauge blunt needle attached to Nanofil syringe (World Precision Instruments) coupled to an UltraMicroPump II (World Precision Instruments). The microinjections were performed over $30 \mathrm{~s}$ and the needle was left in place for 

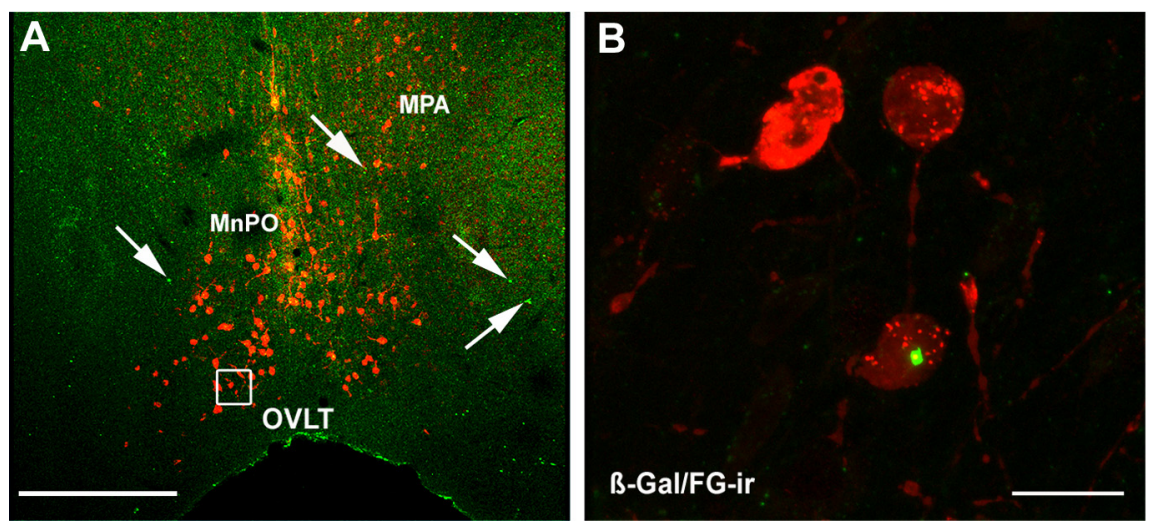

Figure 3. Few MnPO PTH2R neurons project to the DMH. $A, B$, Neurons containing retrograde label (red) are shown in the MnPO following injection of $\mathrm{FG}$ into the DMH of a PTH2R- $\beta$-gal knock-in mouse. $\beta$-gal accumulates within vesicle-like structures in the cell bodies of PTH2R neurons (green dots indicated by arrows in $\boldsymbol{A}$ ). The area indicated by the square in $\boldsymbol{A}$ is shown at higher magnification in $\boldsymbol{B}$. One of three retrogradely labeled cells contains $\beta$-gal-ir. Scale bars: $\boldsymbol{A}, 200 \mu \mathrm{m} ; \boldsymbol{B}, 10 \mu \mathrm{m}$.
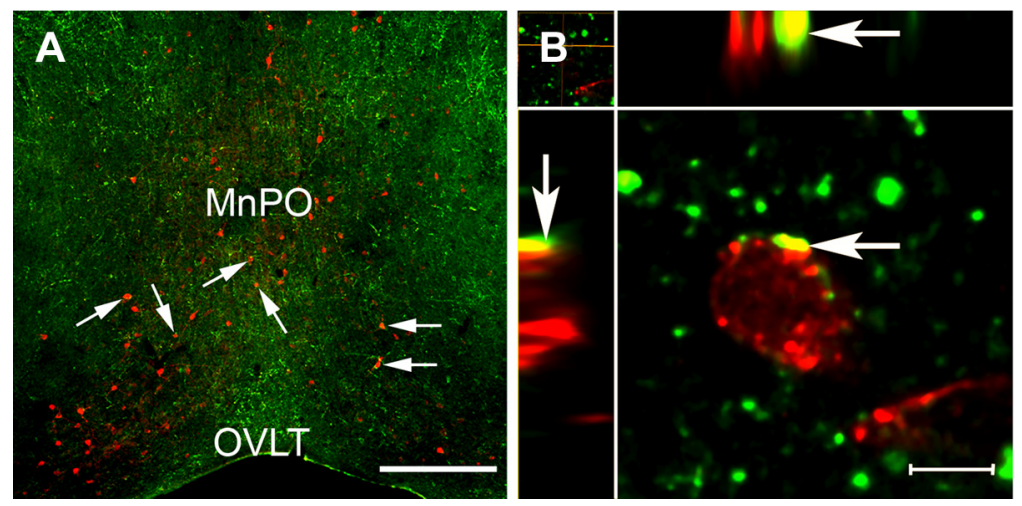

Figure 4. $\mathrm{MnPO}$ neurons that project to the DMH are contacted by PTH2R-ir fibers. $A$, Arrows indicate MnP0 neurons filled with FG (red) from a DMH injection and enmeshed in PTH2R-ir fibers (green). $\boldsymbol{B}$, At higher magnification, PTH2-ir processes appear to contact DMH projecting MnPO neurons. The arrow indicates an area of apparent colocalization, which may be a PTH2R-containing fiber making a contact with an $\mathrm{MnPO}$ projection neuron. $A$ is a single optical section, $B$ is an $X Y Z$ projection of a confocal $Z$-series of 12 optical sections spanning $47.6 \times 47.6 \times 5.6 \mu \mathrm{m}$ with $X$-Z $Z$ images on top and $Y$-Z $Z$ images at the left. Scale bars: $\boldsymbol{A}, 10 \mu \mathrm{m} ; \boldsymbol{B}$ $5 \mu \mathrm{m}$.

another 5 min to minimize back flow. The injected mice were killed 6-7 d after the procedure.

For viral tract tracing, aliquots of GFP-expressing Bartha strain pseudorabies virus PRV-152 (provided by L. W. Enquist, Princeton University, Princeton, NJ; Smith et al., 2000) and PRV-614 expressing red fluorescent protein (mRFP1) (provided by L. W. Enquist (Banfield et al., 2003), were thawed and kept on ice until use. The injection of $1 \mu$ l of the viral solution was made with 30 -gauge needle on a $2 \mu$ l Hamilton syringe after exposure of the interscapular brown tissue pads by a small longitudinal skin incision. Five inoculations were made in a circular pattern and the excessive fluid was absorbed with gauze. The wound was closed with skin clips. The animals were observed twice daily and their weight closely monitored. The PRV-injected mice were killed and perfused for immunolabeling 100-120 h after viral injection, following 20\% body weight loss. PRV-infected cells were identified by the fluorescence of the expressed GFP or mRFP1.

Immunohistochemistry. Deeply anesthetized animals were perfused with $4 \%$ paraformaldehyde and $40 \mu \mathrm{m}$ sections were cut from the brain areas of interest. Immunohistochemistry was performed on freefloating sections as described previously (Dimitrov and Usdin, 2010). Sections were incubated with rabbit antibodies directed at the PTH2R or TIP39 (1:10 000 dilution; $0.1 \mu \mathrm{g} / \mathrm{ml}$; Faber et al., 2007) for $48 \mathrm{~h}$ at $4^{\circ} \mathrm{C}$ followed by primary antibody detection using biotin-labeled donkey anti-rabbit IgG (Jackson ImmunoResearch Laboratories; 1:1000)-, avidin-peroxidase complex (Vectastain Elite, Vector Laboratories)-, and
DyLight 488 (Pierce)-conjugated tyramide as described previously (Dimitrov and Usdin, 2010). Then, sections with PTH2R-ir were incubated with a guinea pig antibody against VGlut2 (provided by J. D. Erickson, Louisiana State University, Baton Rouge, LA; 1: 5000), a mouse antibody against microtubuleassociated protein 2 (anti-MAP2; SigmaAldrich, catalog \#M4403; 1:5000), a mouse anti-glutamate decarboxylase (GAD) 65 antibody (Millipore Bioscience Research Reagents, catalog \#MAB351; 1: 1000), or a rabbit anti-FG antibody (Millipore Bioscience Research Reagents; 1:1000), which were visualized with Alexa 594 (Invitrogen)- or DyLight 649 (Jackson ImmunoResearch)-labeled secondary antibodies directed against IgG of the appropriate species. At the PTH2R antibody concentration used it is not visualized with the Alexa 594 antirabbit antibody. Controls in which the FG antibody was omitted confirm the lack of signal from the PTH2R antibody without amplification. For $\beta$-Gal/FG labeling, chicken anti- $\beta$ Gal antibody (Abcam) was diluted 1:10 000 followed by $\mathrm{ABC} /$ Tyramide amplification combined with FG staining as described above. For GFP/PRV-614 labeling anti-GFP (Abcam \#290) was diluted 1:5000 and detected with DyLight 488 anti-rabbit while PRV-614 encoded red fluorescent protein was directly visualized. The antibodies to FG, $\beta$-Gal and GFP produced no signal in control mice. The PTH2R antibody was raised against a C-terminal epitope in the receptor and affinity purified using that peptide. It labels material with the appropriate molecular weight on Western blots of cells transfected with the receptor cDNA, using immunocytochemistry cells transfected with the receptor cDNA and not the parent cell line are labeled (Usdin et al., $1999 \mathrm{~b}$ ), and when used to label rat or mouse brain sections it has a labeling pattern that very closely matches the pattern of the receptor's mRNA detected by in situ hybridization (Faber et al., 2007). The antibody to TIP39 was raised against the full-length synthetic peptide and affinity purified. Labeling is absent in brain sections from TIP39 knock-out mice (Fegley et al., 2008). The VGlut2 antibody labels extracts from VGlut2-expressing cells but not parent PC12 orVGlut1- or VGlut3-expressing cells (Schäfer et al., 2002). The labeling patterns obtained with PTH2R, TIP39, and VGlut2 antibodies were the same as that previously described for the corresponding antigen (Varoqui et al., 2002; Faber et al., 2007). According to the manufacturer the MAP2 antibody was raised against rat microtubule associated proteins, reacts with MAP2a, MAP2b and MAP2c, does not cross-react with other MAPs or tubulin and by immunohistochemical labeling of formalin-fixed brain tissue shows selective labeling of dendritic trees throughout the brain. The antibody to GAD65 was raised against GAD purified from rat brain (Chang and Gottlieb, 1988) and according to the supplier it recognizes the lower molecular weight of the two GAD isoforms present in rat brain on Western blot.

The anatomical levels of sections and specific regions were identified using the Franklin and Paxinos (2008) atlas. Immunolabeling was visualized in representative sections using a Zeiss LSM 510 confocal microscope in the NINDS Intramural Light Imaging Facility. Z-series were analyzed using Volocity software (Improvision) by selecting XYZ mode for $3 \mathrm{D}$ data.

Fluorescence in situ hybridization histochemistry. A group of six animals was injected in the DMH with $0.1 \mu \mathrm{l}$ of rhodamine latex beads. Four of these animals had injections confined to the DMH and their brains were 

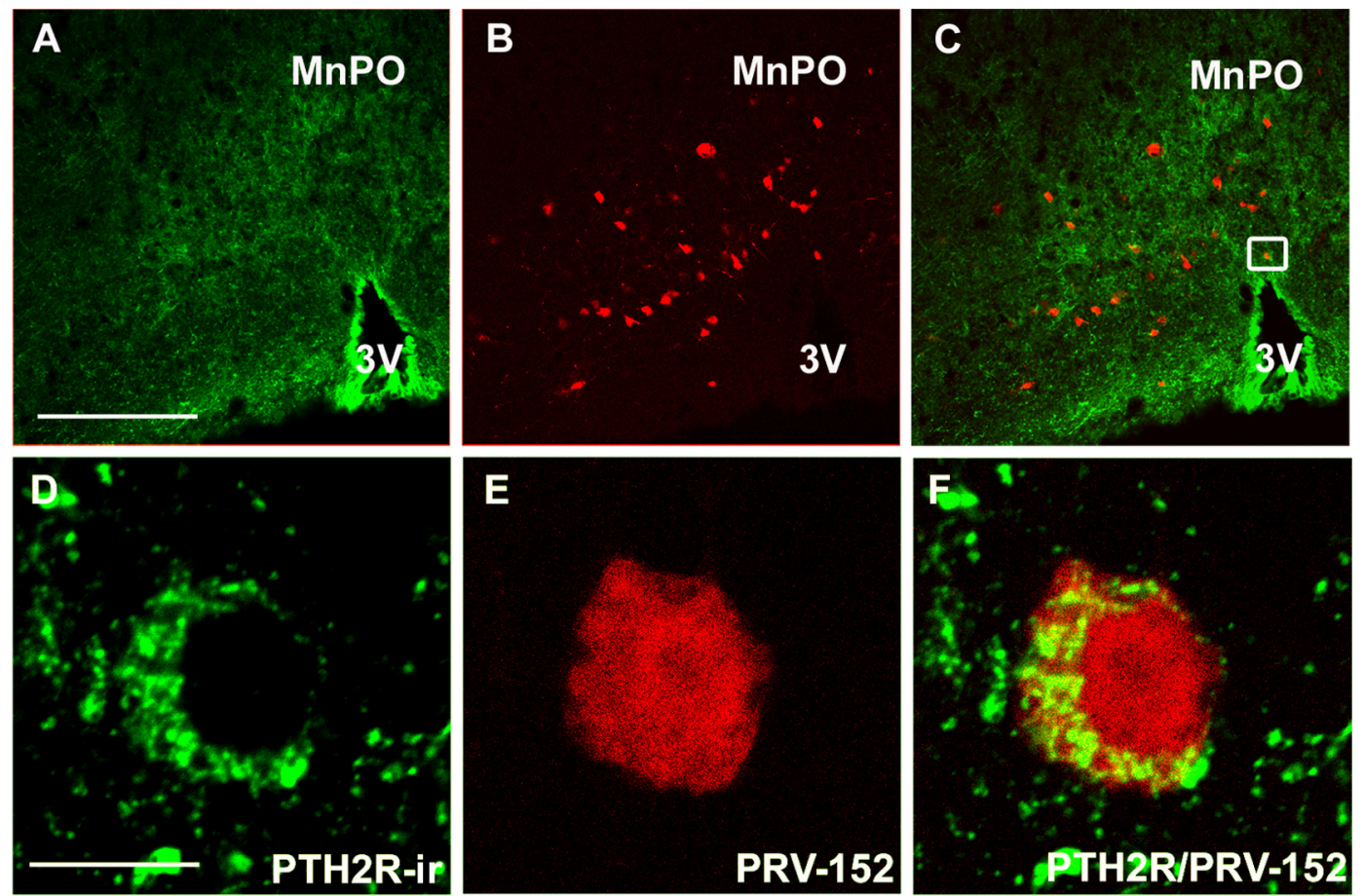

G

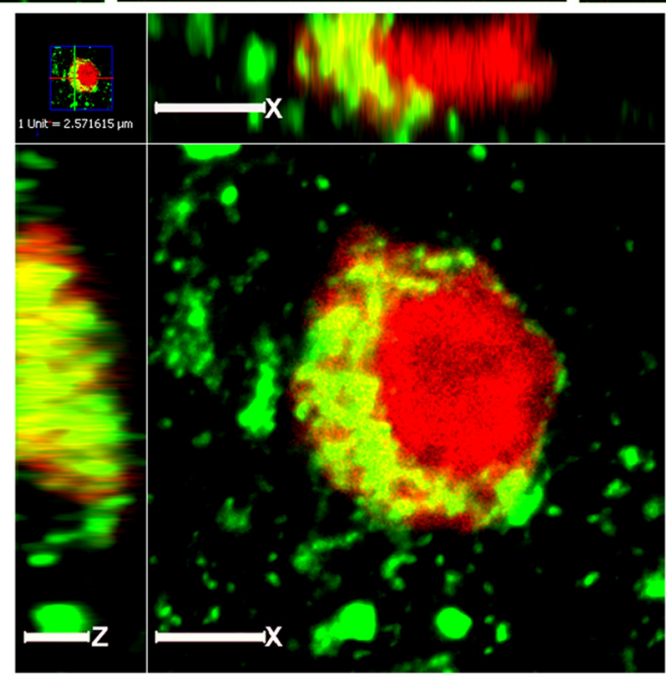

Figure 5. PRV infection of a PTH2R-ir cell in the MnPO. Five days following BAT injection, PRV-152-infected cells are observed in the preoptic hypothalamus (A-C). A PRV-infected cell with PTH2R-ir on its surface is indicated by the rectangle in $\mathbf{C}$ and shown at high magnification in $\boldsymbol{D}-\mathbf{G}$. Single optical sections are shown in $\boldsymbol{D}-\boldsymbol{F}$. The image in $\boldsymbol{G}$ is an XYZ plane representation of a $Z$-series of 12 optical sections spanning $47.6 \times 47.6 \times 3.4 \mu \mathrm{m}$. The $X-Z$ (top) and $Y$-Z (left) views confirm the colocalization between the green and red voxels (yellow). Virally encoded GFP is pseudocolored red in all images and PTH2R-ir is green. Scale bars: $\boldsymbol{A}-\boldsymbol{C}, 100 \mu \mathrm{m} ; \boldsymbol{D}-\boldsymbol{F}, 10 \mu \mathrm{m}$. In $\mathbf{G}, 5 \mu \mathrm{m}(X)$ and $2 \mu \mathrm{m}(Z)$ bars are shown.

processed for in situ hybridization. Coronal sections (12 $\mu \mathrm{m}$ thick) were cut through the preoptic hypothalamus from unfixed rapidly frozen brains, thaw mounted onto positively charged slides and stored at $-80^{\circ} \mathrm{C}$ until hybridization. Fluorescent in situ hybridization was performed as previously described (Dimitrov and Usdin, 2010), with reduction of the time for ethanol dehydration and omitting the chloroform delipidation to preserve the rhodamine latex beads. The GAD67 probe was a 511 base-pair PCR product corresponding to bases 2618-3128 of GenBank accession \# NM_008077. The VGlut2 probe was a 426 base-pair product corresponding to bases 2132-2558 of GenBank accession \# NM_080853.

Coronal brain sections were atlas matched according to the mouse brain atlas of Franklin and Paxinos. Images of the paraventricular nucleus of the hypothalamus area were acquired using 405, 488, and $543 \mathrm{~nm}$ lasers on a Zeiss LSM 510 confocal microscope. The tissue background and the DAPI staining permitted visualization of landmarks and cell nuclei, including the MnPO, MPO, organum vasculosum of the lamina terminalis (OVLT), and third ventricle. Images covering the entire
MnPO were collected from atlas-matched sections. Only cells with rhodamine beads visible on both sides of the DAPI-labeled nucleus were identified as retrogradely labeled and only those retrogradely labeled cells with $>4-5$ clusters of fluorescent mRNA signal were counted as doublelabeled. The nuclear area, as defined by DAPI staining, was measured on a subpopulation of retrogradely labeled cells and there was no detectable difference between the total population and the population of VGlut2- or GAD67-positive cells so no stereological correction was performed.

Statistical analysis. Data are presented as mean \pm SEM. Student's $t$ test was used for two group comparisons. The area under the curve was calculated from temperature time course measurements for each animal using the trapezoidal approximation method in GraphPad Prism and data were then grouped for statistical analysis. One-way ANOVA with repeated measures followed by Newman-Keuls Multiple Comparison Test was used for drug dose responses and two-way ANOVA followed by Bonferroni post-test for experiments evaluating drug and genotype interaction. The accepted level of significance was $p<0.05$ in all tests. 

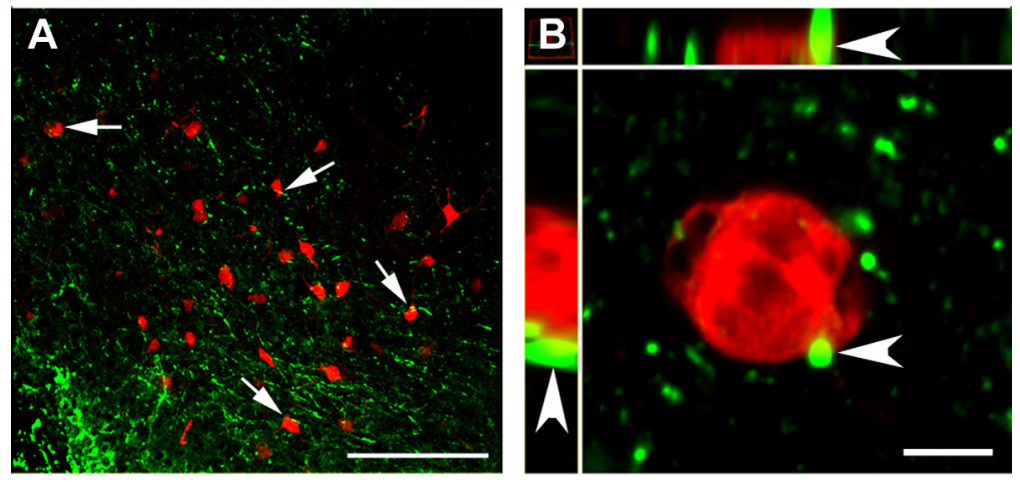

Figure 6. PTH2R-ir processes appear to contact PRV-infected cells in the MnP0.A, Multiple cells infected with PRV-152 (red) are found in the MnPO following BAT injection of the virus. PTH2R-ir fibers are adjacent to many of the PRV-infected cells, some of which are indicated with arrows. The arrowhead in $B$ indicate an area of PTH2R-ir in apparent contact with a PRV-152-infected cell. The image is presented as an $X Y Z$ plane from a confocal $Z$ series covering $47.6 \times 47.6 \times 5.6 \mu \mathrm{m}$, with $X$ - $Z$ image on top and $Y$ - $Z$ image at the left of the panel. Scale bars: $\boldsymbol{A}, 100 \mu \mathrm{m} ; \boldsymbol{B}, 5 \mu \mathrm{m}$.

\section{Results \\ Retrograde tract tracing places MnPO PTH2R neurons in a thermoregulatory circuit}

PTH2R-ir and TIP39-ir are present on fibers and terminals throughout the preoptic area (Fig. 1). This includes the MnPO, which we consider to be a dorsally elongated triangular area situated directly above and closely surrounding the OVLT, which is adjacent to the tip of third ventricle (Fig. 1), as used by Saper and colleagues in rat (Yoshida et al., 2009) and mouse (Lazarus et al., 2007). The MnPO corresponds to a region of somewhat increased cell density visible in nuclear or Nissl stained material (data not shown). PTH2R-expressing cell bodies are not often detected by the PTH2R antibody but their presence throughout the preoptic hypothalamic region is demonstrated by in situ hybridization detection of PTH2R mRNA (Faber et al., 2007; Lein et al., 2007) and by immunohistochemical detection of $\beta$-Gal in sections from transgenic mice with $\beta$-Gal knocked into exon 1 of the PTH2R gene (Fig. $1 C$ ), which provides a cell body marker for PTH2R-expressing cells (Faber et al., 2007). $\beta$-gal accumulates within small vesicle-like structures in PTH2Rexpressing neurons of PTH2R- $\beta$-gal knock-in mice (Faber et al., 2007; see below). We previously observed colocalization between PTH2R-ir and VGlut2-ir in several brain regions, in rodent and non-human primate (Dobolyi et al., 2006; Dimitrov and Usdin, 2010), including the medial preoptic area (Bagó et al., 2009), which places the receptor on glutamatergic axonal terminals. We found that this is also the case in the mouse MnPO (Fig. 2I). In contrast, we observed no colocalization between PTH2R-ir and either GAD65-ir (Fig. 2C) or the dendritic marker MAP2 (Fig. $2 F$ ). Based on previous lesion, tracing, and double labeling studies, TIP39-ir fibers in this area are projections from neurons in the thalamic subparafascicular area that do not express PTH2Rs (Dobolyi et al., 2003b; Palkovits et al., 2010). Thus, PTH2R-ir and TIP39-ir are present in or on distinct axonal processes or nerve terminals within the MnPO.

To evaluate the potential relationship of MnPO PTH2Rexpressing neurons with thermoregulatory circuitry we injected the retrograde tracer FG into the DMH of PTH2R- $\beta$-gal knock-in mice. However, despite the overlap between areas with a relatively high density of PTH2-ir fibers and retrogradely labeled cells, only a few of the FG-labeled neurons contained $\beta$-Gal-ir (Fig. 3). The majority of the $\beta$-Gal marked cells in this region were just outside the $\mathrm{MnPO}$ as defined by the retrogradely labeled neurons (Fig. 3A; see also Fig. 1C). Still, all of the retrogradely labeled neurons in the $\mathrm{MnPO}$ and medial preoptic area (MPA) were enmeshed in PTH2R-ir fibers (Fig. 4A). Close appositions between FG-labeled cells and PTH2R-ir fibers (Fig. $4 B$ ) suggests that PTH2Rexpressing cells make functional contacts with MnPO projection neurons. Based on PTH2R-ir/VGlut2-ir colocalization these appear to be excitatory contacts.

To further evaluate the potential involvement of preoptic PTH2 receptorexpressing neurons in thermoregulatory pathways we injected the GFP-expressing Bartha strain pseudorabies virus PRV-152 into interscapular BAT and performed immunolabeling of brain sections with a PTH2 receptor antibody. This virus provides transneuronal retrograde labeling of the hierarchy of neurons that give rise to the autonomic innervation of peripheral organs. The general pattern of neuronal labeling matched that previously described (Oldfield et al., 2002; Cano et al., 2003; Yoshida et al., 2003; Voss-Andreae et al., 2007). Brain areas with PRV-152 expression $106 \mathrm{~h}$ following injection were, in ascending order: nucleus of the solitary tract, rostral raphe pallidus, locus ceruleus, parabrachial nucleus, parts of the dorsal lateral hypothalamus, $\mathrm{DMH}$, retrochiasmatic area, hypothalamic paraventricular nucleus, MPA, MnPO (Fig. 5), dorsolateral preoptic area and parts of the sensory cortex. The intensity of the viral expression generally decreased from caudal to rostral regions. The MnPO surrounding the OVLT contained numerous neurons with varying amounts virally encoded fluorescent protein (Fig. 5). There was clear colocalization between PTH2R-ir and the viral expressed protein in a small number of cells. Figure 5 shows a PRV-infected cell that is also PTH2R-ir positive. Many of the PRV cells were surrounded by PTH2R-ir fibers, which often formed close appositions (Fig. 6), similar to the observation made following DMH injection of FG. This places MnPO PTH2 receptor signaling within the extended circuitry associated with innervation of BAT.

\section{MnPO glutamatergic neurons project to the $\mathrm{DMH}$}

To further characterize the $\mathrm{DMH}$ projecting $\mathrm{MnPO}$ neurons we injected rhodamine latex beads into the $\mathrm{DMH}$ and performed in situ hybridization with VGlut2 and GAD67 mRNA probes on sections containing the MnPO. Microinjection of $0.1 \mu \mathrm{l}$ of rhodamine latex beads into the DMH labeled numerous cells in the MPA and MnPO with a pattern like that described previously (Nakamura et al., 2005; Yoshida et al., 2009) and observed with FG injection (above). Most of the labeled neurons were within the limits of the MnPO (Figs. 7A, G, 8). As described previously (Grob et al., 2003; Lin et al., 2003), VGlut2 mRNA and GAD67 mRNA was expressed throughout the preoptic area with a relatively high density in the MnPO (Fig. $7 \mathrm{~B}, \mathrm{H}$ ). We evaluated atlasmatched sections from four levels of the MnPO $(+0.62,0.50$, 0.38 and $0.26 \mathrm{~mm}$ from bregma; Fig. 8) and established a stringent criterion for double-labeled cells (see Materials and Methods). Using these criteria, an average of $23.5 \pm 3.8 \%$ of the rhodamine bead-labeled neurons (129 \pm 22.8 retrogradely labeled cells evaluated per animal) coexpressed VGlut 2 mRNA and an average of $9.7 \pm 0.8 \%$ of the retrogradely labeled neurons were double-labeled with GAD67 mRNA $(118 \pm 20.3$ cells evaluated 

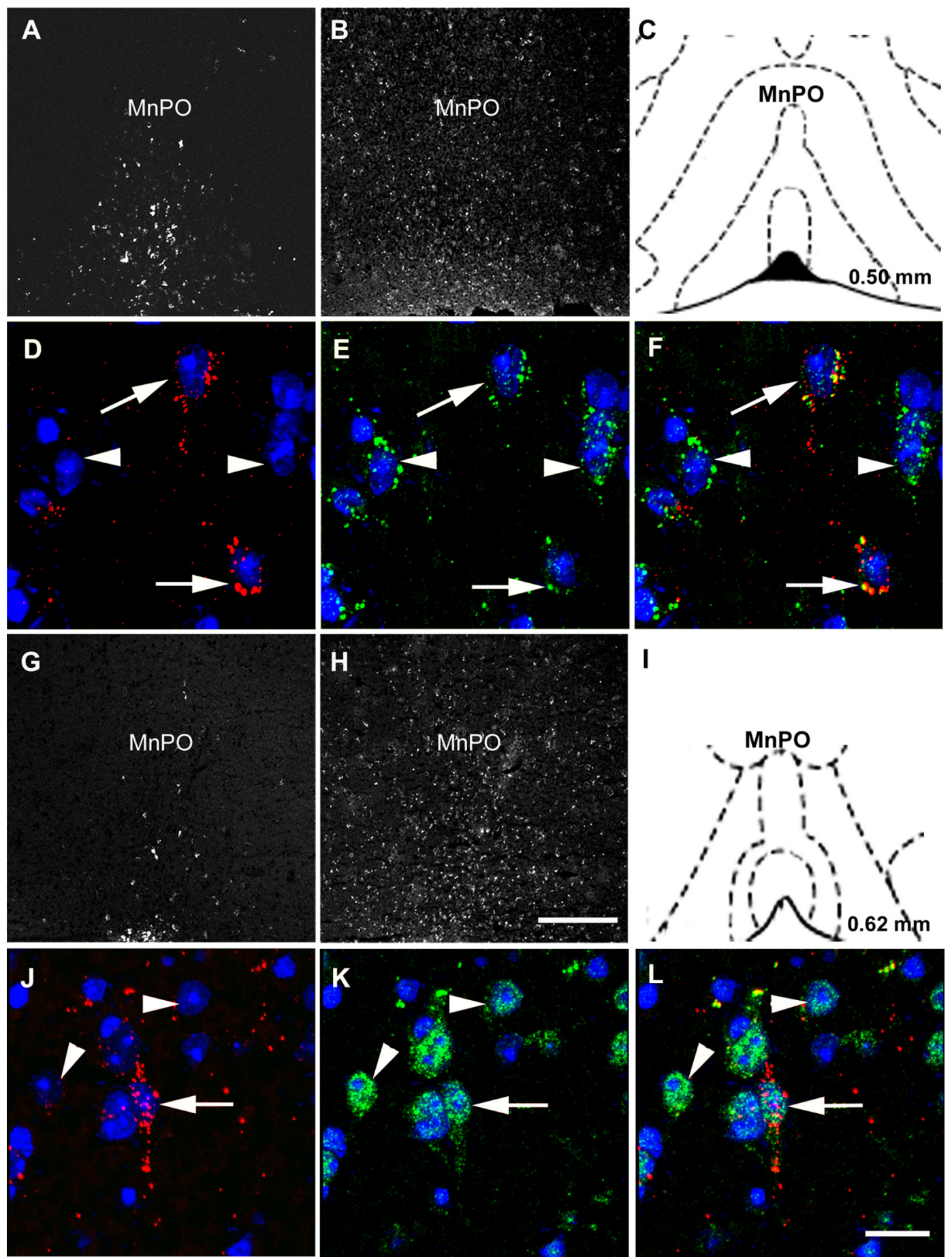

Figure 7. MnPO glutamatergic and GABAergic neurons project to the DMH. Rhodamine latex beads were injected into the DMH. The general distribution of rhodamine bead-containing cells ( $\boldsymbol{A}$, $\boldsymbol{G})$ overlaps the distribution of cells containing VGlut2 $\mathrm{mRNA}(\boldsymbol{B})$ and GAD67 mRNA $(\boldsymbol{H})$ as detected by fluorescent in situ hybridization. Adjacent diagrams $(\boldsymbol{C}, \boldsymbol{I})$ indicate the approximate shape of the MnP0 at the levels illustrated. DAPI (blue) counter staining helps to show the location of cell bodies containing rhodamine beads (red, $\boldsymbol{D}$ and $\boldsymbol{J}$ ), VGlut2 mRNA (green, $\boldsymbol{E}$ ) and GAD67 mRNA (green, $\boldsymbol{K}$ ). $\boldsymbol{F}$ and $\boldsymbol{L}$ are merged images in which the arrows show double-labeled cells and the arrowheads single-labeled cells (VGlut2 $\mathrm{mRNA}$ in $\boldsymbol{F}$ and GAD67 mRNA in $\boldsymbol{L}$ ). The fielding $F$ also contains three cells containing VGlut2 mRNA but no rhodamine beads. Scale bars: $A-C, 100 \mu \mathrm{m} ; \mathbf{D}-\boldsymbol{F}, 10 \mu \mathrm{m}$.

per animal). The proportions of VGlut2- and GAD67-expressing cells may be underestimated because of the sensitivity of the fluorescent in situ hybridization technique. However, this experiment clearly establishes a glutamatergic projection from the $\mathrm{MnPO}$ to the $\mathrm{DMH}$, in addition to the previously characterized GABAergic connection (Nakamura et al., 2005, 2009; Yoshida et al., 2009).
Glutamatergic neurons of the preoptic hypothalamus are part of the autonomic circuitry that innervates BAT

Evidence consistent with an excitatory glutamatergic pathway from cold-sensitive $\mathrm{MnPO}$ neurons to the thermoregulatory rostral raphe nucleus, that regulates skin vasoconstriction, has been provided by electrophysiological recording experiments (Tanaka et al., 2011), but MnPO glutamatergic neurons involved in ther- 

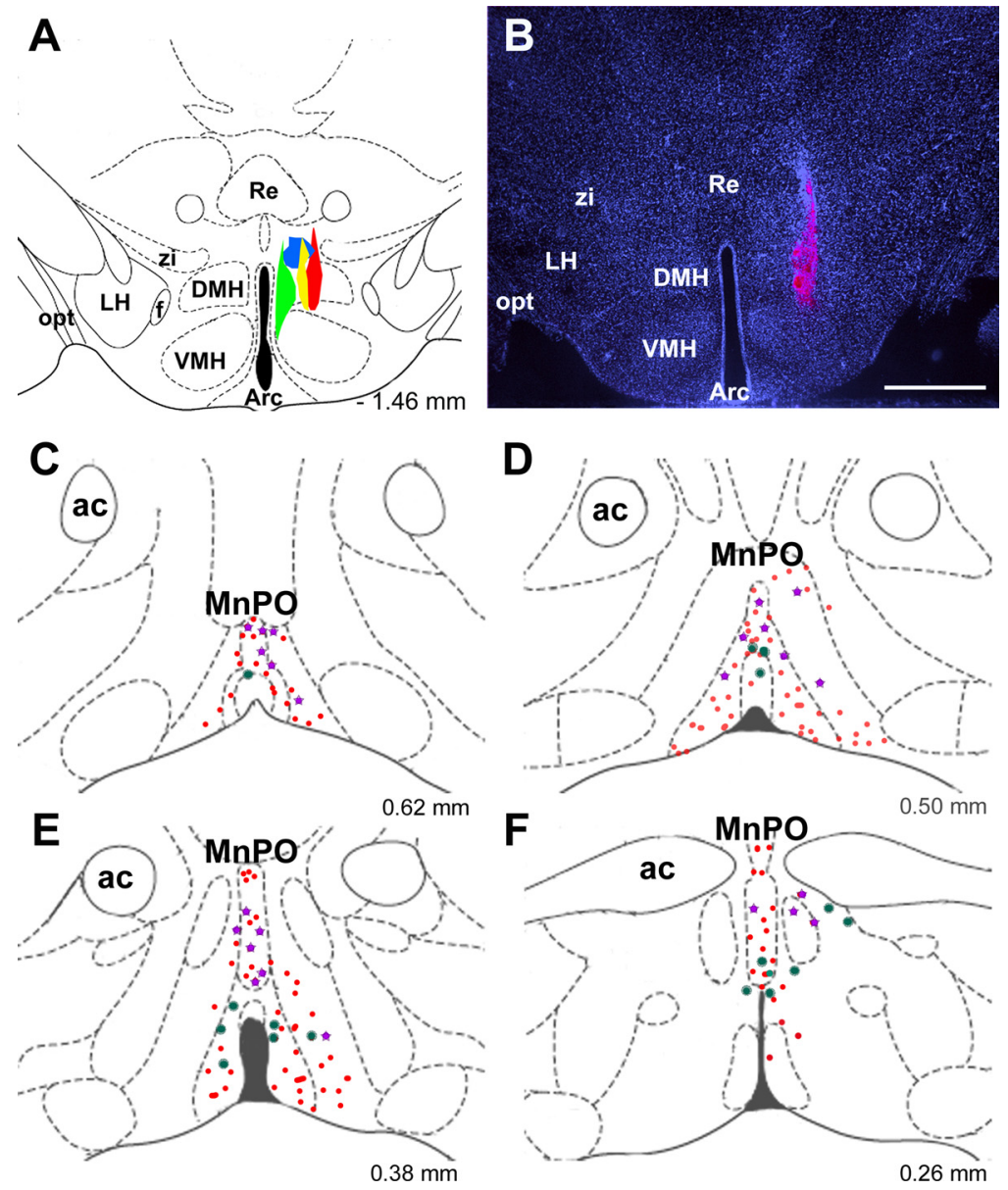

Figure 8. Distribution of neurons projecting from the MnPO to the DMH. $\boldsymbol{A}$, Rhodamine latex bead injection sites in the four animals used for analysis are illustrated. $\boldsymbol{B}$, The injection site in red is shown after counterstaining tissue with DAPI. $\boldsymbol{C}-\boldsymbol{F}$, The distribution of rhodamine-labeled neurons (red dots), VGlut2/Rhodamine (purple stars) and GAD67/Rhodamine (teal circles) coexpressing cells from this animal are illustrated at four levels (distance from bregma indicated on the figure). Scale bar (B), $1 \mathrm{~mm}$. Re, Thalamic reuniens nucleus; zi, zona incerta; Arc, hypothalamic arcuate nucleus.

moregulation have not been identified. To investigate a potential connection between MnPO glutamatergic neurons and the autonomic innervation of BAT, we injected PRV-614 (a pseudorabies virus that encodes red fluorescent protein) into BAT of transgenic mice that express GFP under the control of the VGlut2 promoter. The pattern of PRV-614 in the CNS was similar to that described above for BAT injection of PRV-152. The anatomical distribution of neurons with VGlut2 (GFP) signal matched that of the VGlut2 neuronal populations in the thalamus and anterior hypothalamus determined by in situ hybridization histochemistry (Grob et al., 2003; Barroso-Chinea et al., 2007). In the preoptic hypothalamus GFP-positive cells were concentrated in the MnPO and MPA, as were PRV-614-infected cells (Fig. 9). Both areas contained cells expressing both VGlut2, detected as GFP, and infected by PRV614 , detected as red fluorescent protein.

\section{Intracerebral administration of TIP39 increases body temperature}

To directly test the involvement of hypothalamic PTH2Rexpressing cells in thermoregulation we needed to implement a method for measurement of temperature in mice. We evaluated interscapular implantation of small thermosensitive chips (BioMedic Data Systems, model IPTT-300) as a minimally invasive approach to measuring mouse body temperature. Use of these chips has been validated for studying the fever response to bacterial infection in mice (Kort et al., 1998), and for several types of experiments in larger animals (Chen and White, 2006). The chips are interrogated by bringing a handheld probe within $\sim 2-3$ inches of an animal. We compared the temperature reported by implanted chips with that from a rectal probe by performing both types of measurement in a group of five wild-type mice. The temperature of each animal was measured by both methods hourly for $6 \mathrm{~h}$. The mean temperature reported by the implanted chips was $36.7 \pm 0.3^{\circ} \mathrm{C}$ and from the rectal probe $36.5 \pm 0.2^{\circ} \mathrm{C}$ and there were no significant differences between the two temperature measurements at any time point. From this we concluded that interscapular chips provided an adequate technique for monitoring changes in mouse body temperature and used this approach for all subsequent experiments.

Vehicle or 50, 100, or 200 pmol of TIP39 in $0.1 \mu$ l was microinjected via MnPO cannulae in a group of experimental animals and body temperature was recorded every hour for a period of $8 \mathrm{~h}$. The temperature increased during the first hour in all groups, with no difference between the groups (Fig. 10A). The temperature did not increase further in animals injected with vehicle or $50 \mathrm{pmol}$ of TIP39 (Fig. $10 A, B$ ). Starting with the $2 \mathrm{~h}$ time point there was a clear increase over controls in the temperature of animals administered 100 and 200 pmol of TIP39 (Fig. 10A, B, ANOVA, $F_{(3,15)}=6.7, p<$ 0.05 for vehicle vs TIP39 $100 \mathrm{pmol}$ and for vehicle vs TIP39 $200 \mathrm{pmol})$. The temperature rise peaked at the third hour after the injection with an average increase of $1.9 \pm$ $0.5^{\circ} \mathrm{C}$ for the $100 \mathrm{pmol}$ dose and $2.0 \pm 0.2^{\circ} \mathrm{C}$ for the $200 \mathrm{pmol}$ dose over the experimental groups starting temperature, or $1.5^{\circ} \mathrm{C}$ for each dose above the temperature of the control group at the same time point. This increase lasted for $\sim 4 \mathrm{~h}$ for the $100 \mathrm{pmol}$ and $5 \mathrm{~h}$ for the $200 \mathrm{pmol}$ dose (Fig. 10A).

The DMH plays a significant role in temperature control. It is a relay between the $\mathrm{MnPO}$ and distal areas that control thermogenesis, and its activation leads to a temperature increase ( $\mathrm{Za}$ retskaia et al., 2002; Hunt et al., 2010). It also contains abundant TIP39-ir and PTH2R-ir nerve fibers as well as PTH2R-expressing neurons. We examined the effect of TIP39 microinjection into the $\mathrm{DMH}$ via bilateral cannulae. In contrast to MnPO delivery, microinjection of $100 \mathrm{pmol}$ of TIP39 into the DMH did not significantly affect body temperature (Fig. 10C).

A potential concern with ligand administration through implanted cannula guides is that the guide can cause local inflammation, which in turn can lead to augmentation of temperature upon drug injection, via release of inflammatory mediators. To assure that TIP39 effects on body temperature are independent of local inflammatory factors in the $\mathrm{MnPO}$, and are specific for PTH2R activation, lateral ventricle injections were performed in wild-type and in PTH2R-KO mice. Lateral ventricle administra- 

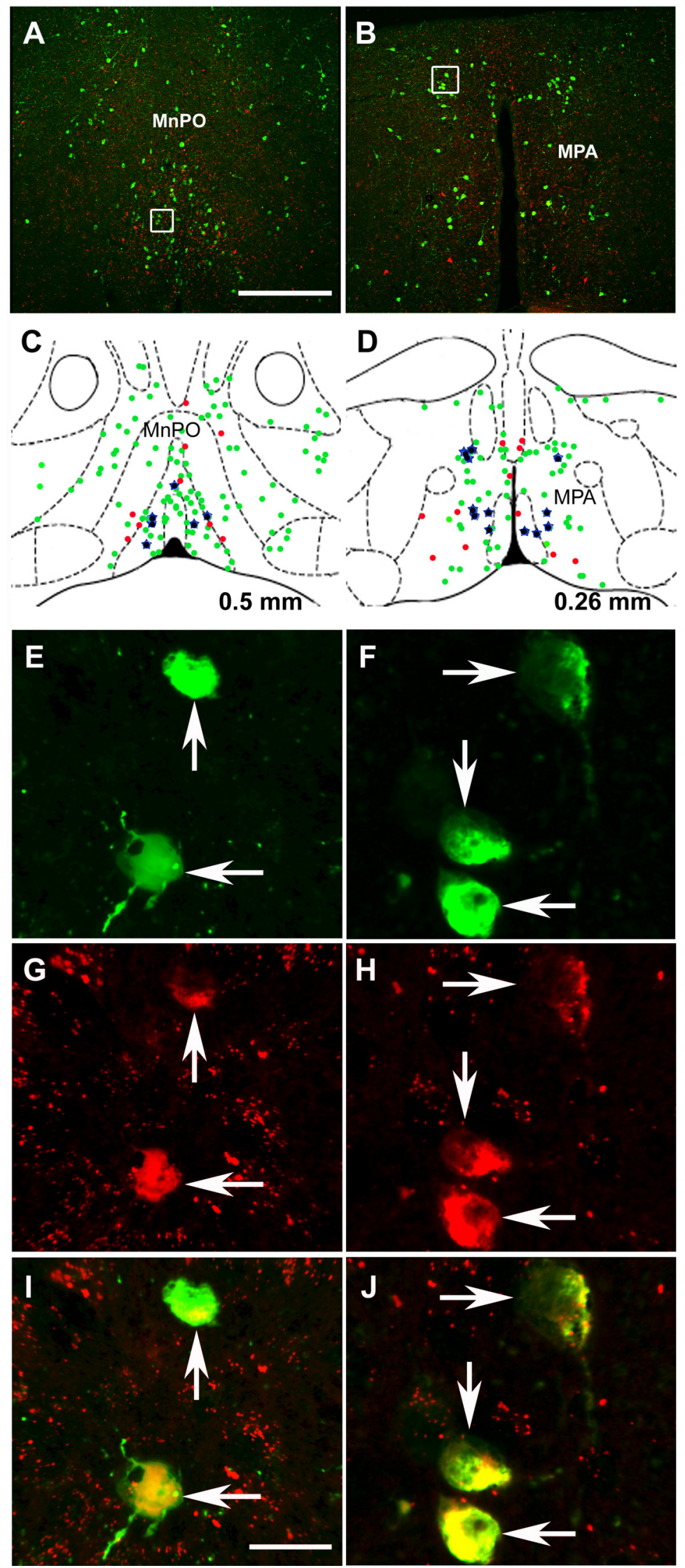

Figure 9. BAT-injected PRV infects preoptic glutamatergic neurons. $\boldsymbol{A}, \boldsymbol{B}$, PRV-614-infected cells (red) and VGlut2-GFPexpressing neurons (green) are shown at two levels of the preoptic hypothalamus (bregma $+0.5 \mathrm{~mm}$, left; $+0.26 \mathrm{~mm}$, right) after injection of the tracer virus into BAT of a VGlut2-GFP BAC transgenic mouse. C, D, The distribution of neurons containing GFP (green dots), PRV-614 (red dots), or both markers (blue stars) at these two levels is shown. High-magnification images taken from the tion of 500 pmol of TIP39 significantly increased body temperature in the wildtype mice (mean of $0.9 \pm 0.2^{\circ} \mathrm{C}$ ) compared with the vehicle infused group (Fig. $11 A, B, \operatorname{ANOVA}(B), F_{(3,28)}=3.9, p<$ $0.05)$ while the temperature of PTH2R-KO mice infused with vehicle or the same dose of TIP39 did not differ from vehicle-treated wild-type animals.

The sympathetic nervous system is the common output pathway for known brain circuits that control body temperature. Activation of sympathetic ganglion cells leads to peripheral vasoconstriction and increased heat production by BAT. Norepinephrine release and activation of $\beta 3$ adrenergic receptors in BAT is pivotal for heat production by small animals, including mice. To confirm that TIP39 increases body temperature via activation of the sympathetic nerve system, we injected TIP39 into the MnPO of mice pretreated with the peripherally acting $\beta$-adrenergic blocker nadolol. Nadolol administration prevented the initial rise in temperature observed with most intracerebral injections, which is likely to be stress-induced hyperthermia (Fig. 12). Nadolol also blocked the temperature rise associated with injection of TIP39 into the MnPO. Body temperature increased only in mice receiving TIP39 without nadolol (Fig. 12A,B, $\operatorname{ANOVA}(B), F_{(3,27)}=6.4, p<0.01$ for TIP39/nadolol vs TIP39/saline and $p<$ 0.05 for vehicle/saline vs TIP39/saline).

\section{Mice lacking TIP39 signaling have impaired ability to defend body temperature against cold}

The baseline body temperature of wildtype and PTH2R-KO mice was not significantly different at the beginning of the experiments and their daily pattern was the same (Fig. 13A). Wild-type mice placed in a $4^{\circ} \mathrm{C}$ environment for $1 \mathrm{~h}$ had little change in body temperature. In contrast, there was a large $\left(3.6 \pm 0.7^{\circ} \mathrm{C}\right)$ decrease in the temperature of PTH2R-KO mice, which was highly significant when compared with the temperature of wild-type after cold exposure (Fig. 13B, two-way ANOVA, $F_{(14,3)}$; significant effect of genotype, $p<0.001)$. The body temperature of both wild-type and PTH2R-KO mice increased following expo-

$\longleftarrow$

outlined areas in $\boldsymbol{A}(\boldsymbol{E}, \boldsymbol{G}, \boldsymbol{I})$ and $\boldsymbol{B}(\boldsymbol{F}, \boldsymbol{H}, \boldsymbol{J})$ show VGlut2-GFP neurons $(\boldsymbol{E}, \boldsymbol{F})$ containing PRV-614 $(\boldsymbol{G}, \boldsymbol{H})$ in which the markers colocalize $(\boldsymbol{I}, \boldsymbol{J})$. In the high-magnification images $(\boldsymbol{E}-\boldsymbol{J})$, arrows indicate GFP/PRV-614 double-labeled cells. Scale bar (in A) A, B, $200 \mu \mathrm{m}$; (in I) $\boldsymbol{E}-\boldsymbol{J}, 10 \mu \mathrm{m}$. 

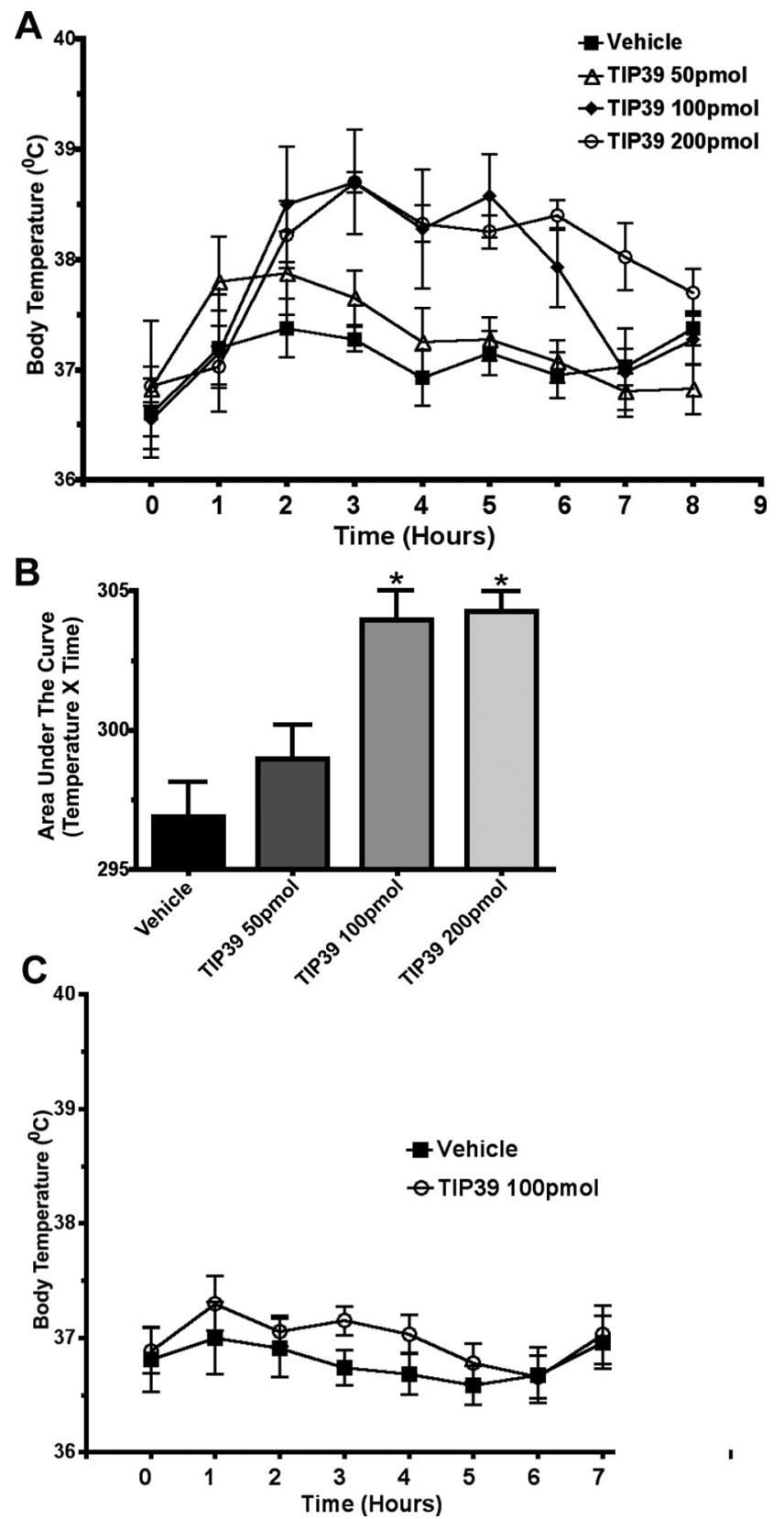

Figure 10. Body temperature following hypothalamic microinjection of TIP39. Vehicle or 50 , 100 , or $200 \mathrm{pmol}$ of TIP39 was microinjected into the MnPO and body temperature measured hourly $(\boldsymbol{A})$. Area under the curve measurements $(\boldsymbol{B})$ indicate significant increases for the groups receiving 100 or 200 pmol of TIP39. TIP39 microinjected into the DMH did not have an effect on body temperature (C). ${ }^{*} p<0.05$.

sure to a hot $\left(35^{\circ} \mathrm{C}\right)$ environment for $1 \mathrm{~h}$ with no difference between the genotypes (Fig. 13C).

Evaluation of functional deficits in global knock-out animals represents a significant challenge because of the possible compensatory changes in the systems under investigation. To evaluate whether the impaired temperature regulation in PTH2R-KO mice is a consequence of the lack of TIP39 signaling within the brain at the time of the experiment, we repeated the cold exposure experiment in a group of wild-type mice administered 500 pmol of the PTH2R antagonist HYWH via a lateral ventricle cannula. In this experiment the animals were placed at $4^{\circ} \mathrm{C}$ for $2 \mathrm{~h}$ to allow time for HYWH to block the PTH2Rs. HYWH administration produced an effect qualitatively similar to the phenotype


Figure 11. Body temperature following lateral ventricle administration of TIP39. Injection of $500 \mathrm{pmol}$ of TIP39 into the lateral ventricle increased body temperature for several hours in wild-type animals but not in PTH2R-KO mice, seen as a time course $(\boldsymbol{A})$, and in area under the curve measurement $(\boldsymbol{B}) .{ }^{*} p<0.05$.

of the PTH2R-KO mice in this paradigm. HYWH-injected mice lost on average $1.0 \pm 0.3^{\circ} \mathrm{C}$ versus a temperature decrease of only $0.2 \pm 0.2^{\circ} \mathrm{C}$ in the vehicle-injected group (Fig. $13 \mathrm{D}$, two-way ANOVA, $F=7.0$; significant effect of treatment, $p<0.05$ ). In mice left at room temperature, the insertion of the injector cannula and the $5 \mathrm{~min}$ of reagent delivery caused the stress-induced hyperthermia observed in most experiments in both the vehicle and HYWH infused groups. There was no difference between the vehicle and HYWH infused group at any time over $8 \mathrm{~h}$ of temperature monitoring (Fig. 13E). This provides an additional control for the specificity of the effects of TIP39 described above, because HYWH is a peptide that differs from TIP39 at only four of their 39 residues.

Norepinephrine causes a paradoxical decrease in the body temperature of PTH2R-KO mice, indicating impaired cold adaptation

The experiments described above indicate that TIP39 signaling modulates sympathetic activation of BAT under acute conditions. In addition to its acute effects on heat production sympathetic innervation of BAT has a trophic influence on the mass and composition of BAT (Bronnikov et al., 1992). Thus, ongoing or accumulated differences between wild-type and PTH2R-KO mice in the sympathetic input to BAT might be reflected in its function. We evaluated BAT function by peripheral administration of norepinephrine, a method for evaluating non-shivering thermogenesis (Janský, 1973). Acute administration of norepinephrine ( $1 \mathrm{mg} / \mathrm{kg}$, i.p.) did not change the body temperature of wild-type mice. The same dose of norepinephrine (NE) decreased the body temperature of PTH2R-KO mice by $1^{\circ} \mathrm{C} 1 \mathrm{~h}$ 
A
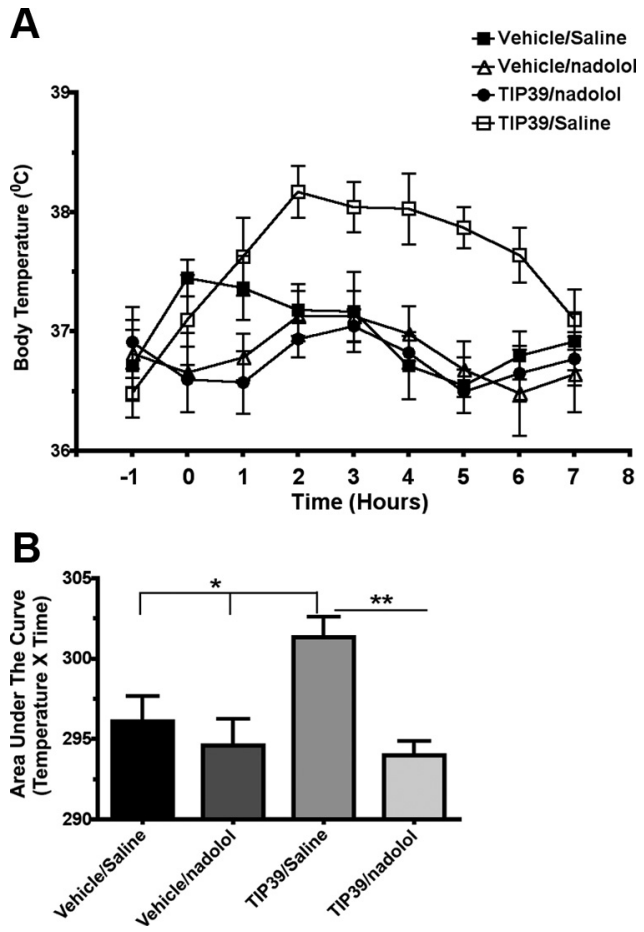

Figure 12. Peripheral $\beta$-adrenergic block prevents TIP39 elevation of body temperature. Pretreatment with nadolol ( $20 \mathrm{mg} / \mathrm{kg}$, i.p.) $1 \mathrm{~h}$ before MnPO injection of TIP39 (100 pmol) or vehicle prevented the small temperature increase observed $1 \mathrm{~h}$ after intracranial injections and blocked the effect of TIP39 $(A)$. Area under the curve measurements indicate that the temperature increase in animals receiving $\mathrm{MnP0}$ injection of TIP39 was significantly greater than either group receiving $\mathrm{MnPO}$ vehicle injection and the group that received $\mathrm{MnPO}$ TIP39 and peripheral nadolol $(\boldsymbol{B}) .{ }^{*} p<0.05,{ }^{* *} p<0.01$.

after injection (Fig. 14A, $B$, ANOVA $(B), F_{(3,22)}=3.8, p<0.05$ for WT/NE vs PTH2R-KO/NE). This paradoxical decrease in temperature is consistent with impaired thermo-adaptation and lower BAT capacity (see Discussion). To confirm the lower BAT capacity of the $\mathrm{KO}$ mice we compared the wet weight of interscapular BAT between wild-type and PTH2R-KO mice. The BAT weight from PTH2R-KO animals was on average $0.14 \pm 0.02 \mathrm{~g}$ versus $0.27 \pm 0.06 \mathrm{~g}$ in wild-type (Student's $t$ test, $n=17 / 13, p<$ $0.001)$. There was no difference between the body weights of the same animals $(\mathrm{PTH} 2 \mathrm{R}-\mathrm{KO}=29.9 \pm 1.1 \mathrm{~g}$ and $\mathrm{WT}=$ $30.6 \pm 1.2 \mathrm{~g})$.

\section{Discussion}

Dense innervation of several hypothalamic nuclei by nerve fibers containing the neuropeptide TIP39 suggests that it modulates multiple homeostatic processes. These fibers originate in the thalamic subparafascicular area (Dobolyi et al., 2003b) and, to date, they have not been found to contain a classic neurotransmitter. Previous studies provide evidence that TIP39 acting on the PTH2R modulates neuroendocrine function, stress response and lactation (Ward et al., 2001; Cservenák et al., 2010; Dimitrov and Usdin, 2010). We now describe TIP39 involvement in temperature control. MnPO microinjection of TIP39 increased body temperature. TIP39's effect was dependent on the PTH2R and on sympathetic nervous system activation. Endogenous TIP39 appears to play an important role in thermoregulation because mice lacking TIP39 signaling, either because of PTH2R genetic inactivation or acute PTH2R antagonist administration are impaired in temperature defense in a cold environment. TIP39's thermoregulatory effects are likely to be mediated through its effect on
PTH2Rs present on glutamatergic nerve terminals that are presynaptic to $\mathrm{MnPO}$ projection neurons. Thus, we speculate that TIP39 may provide thalamic gating of MnPO thermoregulation.

A striking observation was that PTH2R-KO mice placed at $4^{\circ} \mathrm{C}$ have a marked body temperature decrease while wild-type mice maintain a normal temperature. In principle this could result from impaired heat production ability or defect in heat production signals. Both seem to be the case. BAT capacity is impaired, based on a paradoxical body temperature decrease following peripheral norepinephrine injection and on decreased interscapular BAT weight. However, acute intracerebral PTH2R antagonist administration also impaired the heat production response to a cold environment, though to a smaller extent. Thus, TIP39 signaling in the brain contributes to an appropriate response to cold. TIP39 could be involved in temperature sensation since PTH2Rs are present on primary afferent, spinal cord dorsal horn, and lateral parabrachial nucleus neurons. However, we found no difference between wild-type and PTH2R-KO mice in ability to sense cold, as evaluated by time on the $4^{\circ} \mathrm{C}$ and $23^{\circ} \mathrm{C}$ sides in a two-plate thermosensitivity test (data not shown). Thus, we believe that there is less activation of BAT sympathetic premotor neurons in mice without TIP39 signaling, that originates within the brain.

TIP39 could potentially affect thermogenesis via PTH2Rs at several brain sites. Current evidence suggests that glutamatergic neuron terminals within the $\mathrm{MnPO}$ are the principle site. $\mathrm{MnPO}$ microinjection of 100 or 200 pmol of TIP39 produced a large body temperature increase $\left(2^{\circ} \mathrm{C}\right)$ that persisted for several hours. Microinjection of 100 pmol of TIP39 several millimeters away, in the $\mathrm{DMH}$, did not significantly increase temperature despite the presence of PTH2Rs. Lateral ventricle administration of TIP39 increased temperature, but 500 pmol had less effect than 100 pmol microinjected into the MnPO. In other brain areas in which it has been examined there is a high degree of PTH2R/VGlut2 colocalization (Dobolyi et al., 2006; Bagó et al., 2009; Dimitrov and Usdin, 2010; Dimitrov et al., 2010). In this study we found that this is also the case in the MnPO. This places PTH2Rs on glutamatergic presynaptic terminals within the $\mathrm{MnPO}$. The retrograde tracing experiments showed that PTH2R-containing glutamatergic terminals appear to synapse upon MnPO projection neurons. Other investigators suggest that local glutamatergic neurons are a part of the $\mathrm{MnPO}$ thermoregulatory circuitry (Morrison and Nakamura, 2011). Our data place the PTH2R on some of these neurons and position them immediately presynaptic to neurons projecting to the DMH and, indirectly, to BAT.

Two independent thermoregulatory pathways from the preoptic hypothalamus have been described (Nakamura et al., 2009; Yoshida et al., 2009). The first projects to the DMH and from there to the rostral raphe pallidus and is thought to regulate premotor sympathetic output to BAT. GABA is the main transmitter in the initial stage of this pathway (Nakamura et al., 2005). The second pathway, directly from the $\mathrm{MnPO}$ to the rostral raphe pallidus is thought to regulate vasomotor tone (Tanaka et al., 2009). Our retrograde tracing studies point to a robust connectivity between PTH2R terminals and neurons projecting directly to the DMH and to premotor neurons that connect with BAT. In an experiment combining DMH injection of rhodamine latex beads with in situ hybridization detection of VGlut2 or GAD67 mRNA we observed, along with already established GABAergic projections that a number of VGlut2-expressing neurons also project from the MnPO to the $\mathrm{DMH}$. This provides a potential excitatory output from the $\mathrm{MnPO}$ to $\mathrm{DMH}$ which may be modulated by TIP39 signaling. A population of MnPO thermoregu- 
A

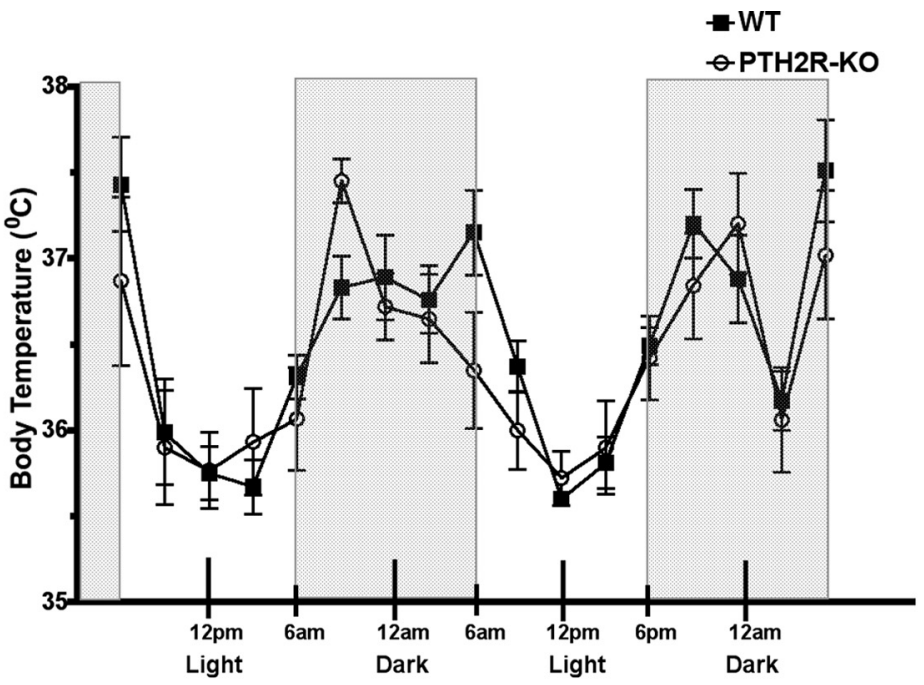

B

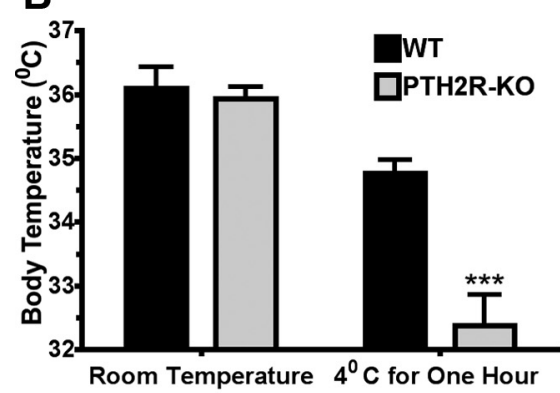

C
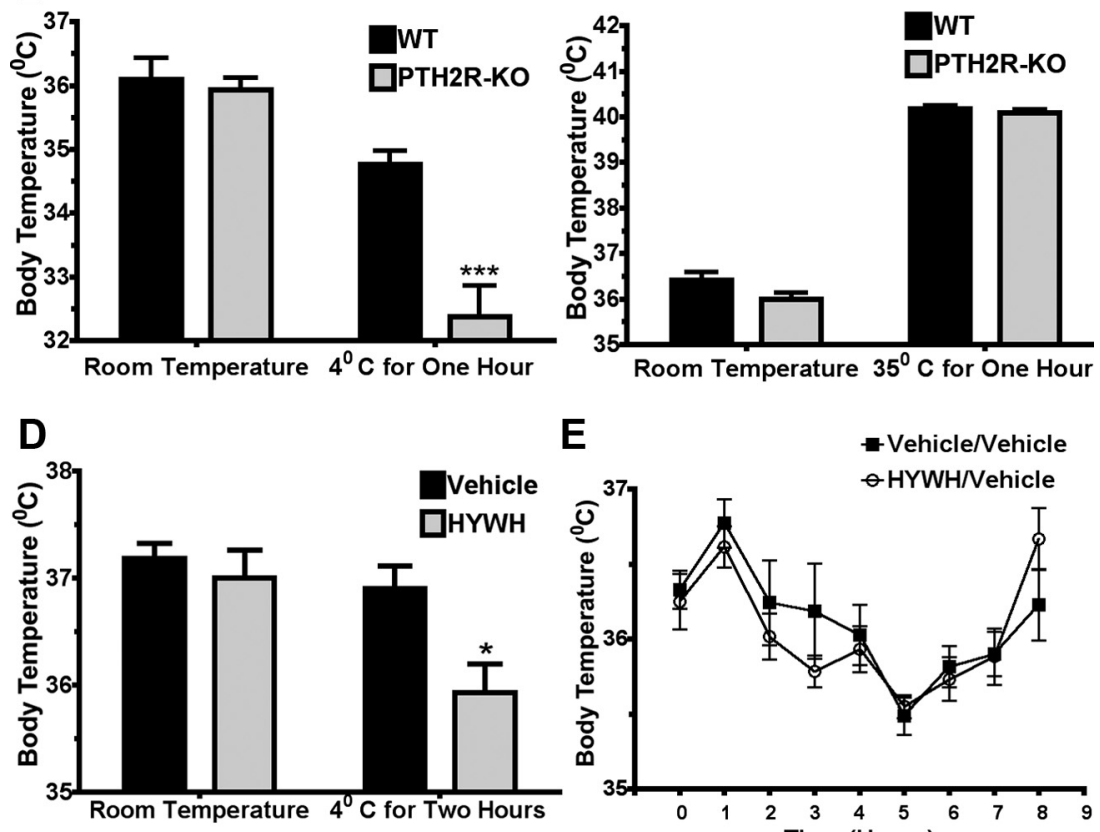

E

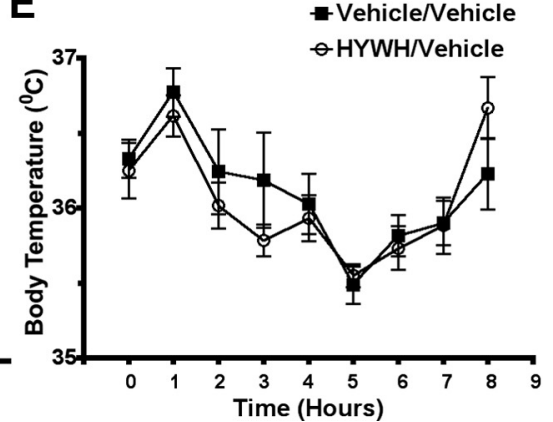

Figure 13. TIP39 signaling is required for an appropriate response to cold. The daily pattern of body temperature was not different between wild-type and PTH2R-KO mice $(\boldsymbol{A})$. PTH2R-KO mice had a much larger decrease in body temperature than wild-type mice following $1 \mathrm{~h}$ cold $\left(4^{\circ} \mathrm{C}\right)$ exposure $(\boldsymbol{B})$, but no difference from wild-type when placed in a hot $\left(35^{\circ} \mathrm{C}\right)$ environment for the same period ( $($ ). Injection of the PTH2R blocker HYWH into the lateral ventricle caused a significant decrease in body temperature in animals exposed to cold (D) but did not affect the temperature of animals that were kept at room temperature $(\boldsymbol{E}) .{ }^{*} p<$ $0.05,{ }^{* * *} p<0.001$.

latory glutamatergic neurons agrees with observations that preoptic hypothalamic glutamate injections activate BAT (Yoshimatsu et al., 1993; Nakamura and Morrison, 2008), and control cutaneous vasoconstriction (Tanaka et al., 2011) and that histamine activates a non-GABAergic population and increases temperature (Lundius et al., 2010). We have not addressed the potential relationship between MnPO PTH2R or VGlut2-expressing neurons and neurons projecting directly to the rostral raphe pallidus because our attempts at raphe pallidus tracer injection resulted in spread to areas, such as the medial longitudinal fasciculus, that would confound its interpretation. However, we did establish, by BAT injection of PRV-614 in VGlut2-GFP mice, that MnPO glutamatergic neurons are connected to BAT. Very likely some of these neurons are the MnPO cold-sensitive excitatory neurons described by oth- ers (Curras et al., 1991; Tanaka et al., 2011). TIP39 activation of BAT thermogenesis may occur via these glutamatergic projection neurons. It is important to note that our data do not exclude the possibility that TIP39 influences thermoregulatory GABAergic signaling in the MnPO.

Basal body temperature is under precise control by warm-sensitive preoptic GABAergic neurons that tonically inhibit $\mathrm{DMH}$ and rostral raphe pallidus sympathetic premotor neurons (Osaka, 2004; Cao et al., 2010). Several stimuli, including pyrogens, raise body temperature by inhibiting these neurons (Tsuchiya et al., 2008; Tanaka et al., 2009). Selective anterior lateral hypothalamic or brainstem knife cuts provide additional support for tonic inhibitory pathways originating in the preoptic hypothalamus but these studies do not exclude existence of an excitatory, on demand, thermoregulatory pathway (Chen et al., 1998; Morrison and Nakamura, 2011). The TIP39/PTH2R system does not regulate the basal body temperature, based on the lack of effect of HYWH administration on temperature and the lack of temperature difference between PTH2R-KO and wild-type mice left at ambient temperature. There is also no difference between the temperature of PTH2R-KO and wild-type mice in a hot environment, indicating intact warmsensitive GABAergic circuitry in these animals. However, our experiments show that intact TIP39 signaling is absolutely necessary when cold exposure raises the demand for heat production by BAT.

One physiological role for TIP39 may be as part of a stressor-specific response to cold. In addition to the requirement for TIP39 signaling in the appropriate response to cold described above, we previously showed that hypothalamic paraventricular nucleus TIP39 microinjection activates the hypothalamic-pituitary-adrenal axis (Dimitrov and Usdin, 2010). Thalamic subparafascicular area TIP39 neurons project to the preoptic area and paraventricular nucleus (Dobolyi et al., 2003b), so a coordinated effect seems likely. TIP39 support of prolactin production may be related, since acute TIP39 signaling block inhibits suckling stimulated prolactin release in lactating rats (Cservenák et al., 2010) and cold exposure increases mouse milk production (Johnson and Speakman, 2001). These effects may be a part of multiple homeostatic functions of TIP39, in which it potentiates glutamatergic signaling to generate an integrated hypothalamic response to adverse physical stimuli.

The TIP39/PTH2R system may also play a role in long-term environmental adaptation. Mammals maintain their temperature within a narrow range through balanced heat production and dissipation. Heat is conserved through piloerection, cutaneous vasoconstriction and body position changes, while shivering 
A
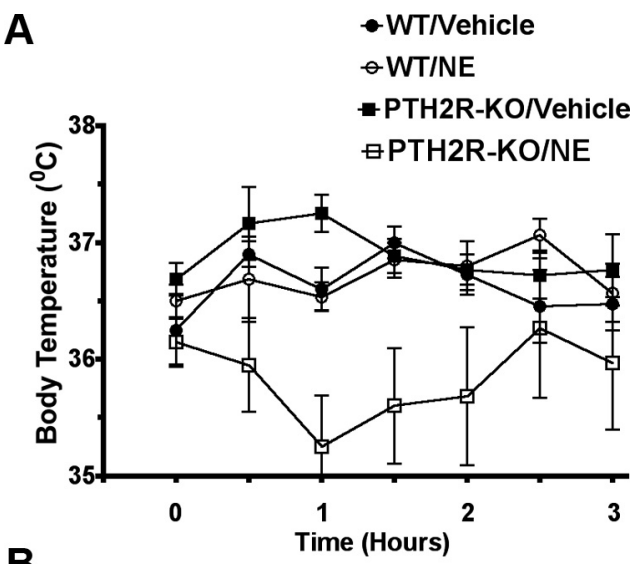

B

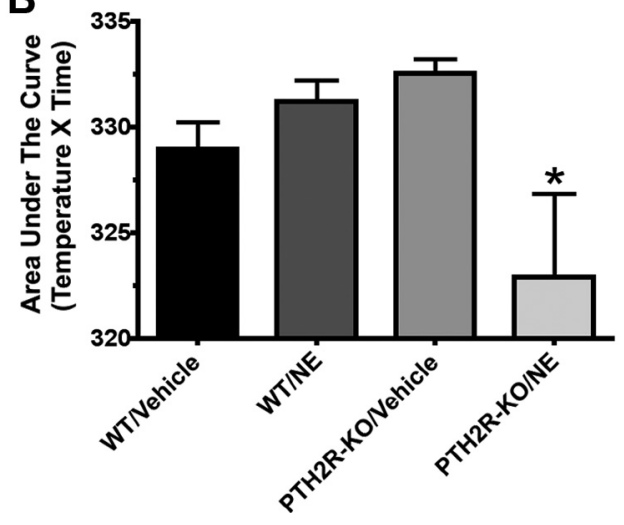

Figure 14. Evidence for impaired BAT function in PTH2R-K0 mice. Peripheral administration of norepinephrine (1 mg/kg, i.p.) did not change the body temperature of wild-type mice but decreased the temperature of PTH2R-KO mice for several hours shown as a time course $(\boldsymbol{A})$ and cumulated area under the curve measurements $(\boldsymbol{B}) .{ }^{*} p<0.05$.

and BAT non-shivering thermogenesis produce heat (Carlisle and Stock, 1993; Cannon and Nedergaard, 2011). These mechanisms are turned off in a thermo-neutral environment, which for rats and mice is $29-30^{\circ} \mathrm{C}$ (Romanovsky et al., 2002; Hodges et al., 2008). Mice adapt to vivarium temperatures of $22-23^{\circ} \mathrm{C}$, which are below their comfort zone, by increasing their metabolic rate (Janský, 1973; Foster and Frydman, 1979; Golozoubova et al., 2004). BAT proliferation, which is under sympathetic drive (Bronnikov et al., 1992), is part of this adaptation. PTH2R-KO mice do not have any overt metabolic deficiency. Their weight and temperature under standard laboratory conditions do not differ from wild-type. However, they have less BAT mass, which suggests impaired adaptation to the vivarium temperature. Peripheral norepinephrine administration allows estimation of non-shivering thermogenesis (Janský, 1973) and BAT capacity (Golozoubova et al., 2004). A norepinephrine-induced "paradoxical" body temperature decrease is well described in animals acutely placed below their acclimated temperature (Zylan and Carlisle, 1992). This may occur because at the acclimated temperature norepinephrine acts on BAT to increase heat production and causes $\alpha$-adrenergic mediated peripheral vasoconstriction which reduces heat dissipation, while in cold to which they are not adapted (Carlisle and Stock, 1993), norepinephrine has less thermogenic effect because of less BAT capacity, and its addition to already elevated endogenous sympathetic release leads to $\beta$-adrenergic mediated increases in peripheral blood flow (for thorough discussion, see Cannon and Nedergaard, 2011). Mice lacking TIP39 signaling may have a BAT capacity/ambient temperature mismatch because of decreased sympathetic trophic ef- fect. Whether this is a relatively selective effect, or part of a general contribution of TIP39 signaling to autonomic function requires further investigation.

In summary, we have shown that there are both glutamatergic and GABAergic projections from the MnPO to the DMH and that a population of $\mathrm{MnPO}$ glutamatergic neurons is connected to BAT. We also show that signaling by the neuropeptide TIP39 and its receptor, which is present on glutamatergic terminals in the MnPO, plays a role in the thermogenic response to cold.

\section{References}

Baffi JS, Palkovits M (2000) Fine topography of brain areas activated by cold stress. A fos immunohistochemical study in rats. Neuroendocrinology 72:102-113.

Bagó AG, Dimitrov E, Saunders R, Seress L, Palkovits M, Usdin TB, Dobolyi A (2009) Parathyroid hormone 2 receptor and its endogenous ligand tuberoinfundibular peptide of 39 residues are concentrated in endocrine, viscerosensory and auditory brain regions in macaque and human. Neuroscience 162:128-147.

Banfield BW, Kaufman JD, Randall JA, Pickard GE (2003) Development of pseudorabies virus strains expressing red fluorescent proteins: new tools for multisynaptic labeling applications. J Virol 77:10106-10112.

Barroso-Chinea P, Castle M, Aymerich MS, Pérez-Manso M, Erro E, Tuñon T, Lanciego JL (2007) Expression of the mRNAs encoding for the vesicular glutamate transporters 1 and 2 in the rat thalamus. J Comp Neurol 501:703-715.

Boulant JA, Silva NL (1988) Neuronal sensitivities in preoptic tissue slices: interactions among homeostatic systems. Brain Res Bull 20:871-878.

Bratincsák A, Palkovits M (2004) Activation of brain areas in rat following warm and cold ambient exposure. Neuroscience 127:385-397.

Bronnikov G, Houstěk J, Nedergaard J (1992) Beta-adrenergic, cAMPmediated stimulation of proliferation of brown fat cells in primary culture. Mediation via beta 1 but not via beta 3 adrenoceptors. J Biol Chem 267:2006-2013.

Cannon B, Nedergaard J (2011) Nonshivering thermogenesis and its adequate measurement in metabolic studies. J Exp Biol 214:242-253.

Cano G, Passerin AM, Schiltz JC, Card JP, Morrison SF, Sved AF (2003) Anatomical substrates for the central control of sympathetic outflow to interscapular adipose tissue during cold exposure. J Comp Neurol 460:303-326.

Cao WH, Madden CJ, Morrison SF (2010) Inhibition of brown adipose tissue thermogenesis by neurons in the ventrolateral medulla and in the nucleus tractus solitarius. Am J Physiol Regul Integr Comp Physiol 299:R277-R290.

Carlisle HJ, Stock MJ (1993) Thermoregulatory responses to betaadrenergic agonists at low ambient temperatures in the rat. Exp Physiol 78:775-786.

Chang YC, Gottlieb DI (1988) Characterization of the proteins purified with monoclonal antibodies to glutamic acid decarboxylase. J Neurosci 8:2123-2130.

Chen PH, White CE (2006) Comparison of rectal, microchip transponder, and infrared thermometry techniques for obtaining body temperature in the laboratory rabbit (Oryctolagus cuniculus). J Am Assoc Lab Anim Sci 45:57-63.

Chen XM, Hosono T, Yoda T, Fukuda Y, Kanosue K (1998) Efferent projection from the preoptic area for the control of non-shivering thermogenesis in rats. J Physiol 512:883-892.

Cservenák M, Bodnár I, Usdin TB, Palkovits M, Nagy GM, Dobolyi A (2010) Tuberoinfundibular peptide of 39 residues is activated during lactation and participates in the suckling-induced prolactin release in rat. Endocrinology 151:5830-5840.

Curras MC, Kelso SR, Boulant JA (1991) Intracellular analysis of inherent and synaptic activity in hypothalamic thermosensitive neurones in the rat. J Physiol 440:257-271.

Dimitrov E, Usdin TB (2010) Tuberoinfundibular peptide of 39 residues modulates the mouse hypothalamic-pituitary-adrenal axis via paraventricular glutamatergic neurons. J Comp Neurol 518:4375-4394.

Dimitrov EL, Petrus E, Usdin TB (2010) Tuberoinfundibular peptide of 39 residues (TIP39) signaling modulates acute and tonic nociception. Exp Neurol 226:68-83.

Dobolyi A, Palkovits M, Usdin TB (2003a) Expression and distribution of 
tuberoinfundibular peptide of 39 residues in the rat central nervous system. J Comp Neurol 455:547-566.

Dobolyi A, Palkovits M, Bodnár I, Usdin TB (2003b) Neurons containing tuberoinfundibular peptide of 39 residues project to limbic, endocrine, auditory and spinal areas in rat. Neuroscience 122:1093-1105.

Dobolyi A, Irwin S, Wang J, Usdin TB (2006) The distribution and neurochemistry of the parathyroid hormone 2 receptor in the rat hypothalamus. Neurochem Res 31:227-236.

Dobolyi A, Palkovits M, Usdin TB (2010) The TIP39-PTH2 receptor system: unique peptidergic cell groups in the brainstem and their interactions with central regulatory mechanisms. Prog Neurobiol 90:29-59.

Faber CA, Dobolyi A, Sleeman M, Usdin TB (2007) Distribution of tuberoinfundibular peptide of 39 residues and its receptor, parathyroid hormone 2 receptor, in the mouse brain. J Comp Neurol 502:563-583.

Fegley DB, Holmes A, Riordan T, Faber CA, Weiss JR, Ma S, Batkai S, Pacher P, Dobolyi A, Murphy A, Sleeman MW, Usdin TB (2008) Increased fear- and stress-related anxiety-like behavior in mice lacking tuberoinfundibular peptide of 39 residues. Genes Brain Behav 7:933-942.

Foster DO, Frydman ML (1979) Tissue distribution of cold-induced thermogenesis in conscious warm- or cold-acclimated rats reevaluated from changes in tissue blood flow: the dominant role of brown adipose tissue in the replacement of shivering by nonshivering thermogenesis. Can J Physiol Pharmacol 57:257-270.

Franklin KB, Paxinos G (2008) The mouse brain in stereotaxic coordinates, third edition. p 360. San Diego: Academic.

Golozoubova V, Gullberg H, Matthias A, Cannon B, Vennström B, Nedergaard J (2004) Depressed thermogenesis but competent brown adipose tissue recruitment in mice devoid of all hormone-binding thyroid hormone receptors. Mol Endocrinol 18:384-401.

Gong S, Zheng C, Doughty ML, Losos K, Didkovsky N, Schambra UB, Nowak NJ, Joyner A, Leblanc G, Hatten ME, Heintz N (2003) A gene expression atlas of the central nervous system based on bacterial artificial chromosomes. Nature 425:917-925.

Grob M, Trottier JF, Drolet G, Mouginot D (2003) Characterization of the neurochemical content of neuronal populations of the lamina terminalis activated by acute hydromineral challenge. Neuroscience 122:247-257.

Hodges MR, Tattersall GJ, Harris MB, McEvoy SD, Richerson DN, Deneris ES, Johnson RL, Chen ZF, Richerson GB (2008) Defects in breathing and thermoregulation in mice with near-complete absence of central serotonin neurons. J Neurosci 28:2495-2505.

Hunt JL, Zaretsky DV, Sarkar S, Dimicco JA (2010) Dorsomedial hypothalamus mediates autonomic, neuroendocrine, and locomotor responses evoked from the medial preoptic area. Am J Physiol Regul Integr Comp Physiol 298:R130-R140.

Janský L (1973) Non-shivering thermogenesis and its thermoregulatory significance. Biol Rev Camb Philos Soc 48:85-132.

Johnson MS, Speakman JR (2001) Limits to sustained energy intake. V. Effect of cold-exposure during lactation in Mus musculus. J Exp Biol 204:1967-1977.

Kort WJ, Hekking-Weijma JM, TenKate MT, Sorm V, VanStrik R (1998) A microchip implant system as a method to determine body temperature of terminally ill rats and mice. Lab Anim 32:260-269.

Kuo J, Usdin TB (2007) Development of a rat parathyroid hormone 2 receptor antagonist. Peptides 28:887-892.

Lazarus M, Yoshida K, Coppari R, Bass CE, Mochizuki T, Lowell BB, Saper CB (2007) EP3 prostaglandin receptors in the median preoptic nucleus are critical for fever responses. Nat Neurosci 10:1131-1133.

Lein ES, Hawrylycz MJ, Ao N, Ayres M, Bensinger A, Bernard A, Boe AF, Boguski MS, Brockway KS, Byrnes EJ, Chen L, Chen L, Chen TM, Chin MC, Chong J, Crook BE, Czaplinska A, Dang CN, Datta S, Dee NR, et al. (2007) Genome-wide atlas of gene expression in the adult mouse brain. Nature 445:168-176.

Lin W, McKinney K, Liu L, Lakhlani S, Jennes L (2003) Distribution of vesicular glutamate transporter-2 messenger ribonucleic Acid and protein in the septum-hypothalamus of the rat. Endocrinology 144:662-670.

Lundius EG, Sanchez-Alavez M, Ghochani Y, Klaus J, Tabarean IV (2010) Histamine influences body temperature by acting at $\mathrm{H} 1$ and $\mathrm{H} 3$ receptors on distinct populations of preoptic neurons. J Neurosci 30:4369-4381.

Morrison SF, Nakamura K (2011) Central neural pathways for thermoregulation. Front Biosci 16:74-104.

Nakamura K, Morrison SF (2008) Preoptic mechanism for cold-defensive responses to skin cooling. J Physiol 586:2611-2620.
Nakamura Y, Nakamura K, Matsumura K, Kobayashi S, Kaneko T, Morrison SF (2005) Direct pyrogenic input from prostaglandin EP3 receptorexpressing preoptic neurons to the dorsomedial hypothalamus. Eur J Neurosci 22:3137-3146.

Nakamura Y, Nakamura K, Morrison SF (2009) Different populations of prostaglandin EP3 receptor-expressing preoptic neurons project to two fevermediating sympathoexcitatory brain regions. Neuroscience 161:614-620.

Oldfield BJ, Giles ME, Watson A, Anderson C, Colvill LM, McKinley MJ (2002) The neurochemical characterisation of hypothalamic pathways projecting polysynaptically to brown adipose tissue in the rat. Neuroscience 110:515-526.

Osaka T (2004) Cold-induced thermogenesis mediated by GABA in the preoptic area of anesthetized rats. Am J Physiol Regul Integr Comp Physiol 287:R306-R313.

Palkovits M, Usdin TB, Makara GB, Dobolyi A (2010) Tuberoinfundibular peptide of 39 residues-immunoreactive fibers in the zona incerta and the supraoptic decussations terminate in the neuroendocrine hypothalamus. Neurochem Res 35:2078-2085.

Romanovsky AA, Ivanov AI, Shimansky YP (2002) Selected contribution: ambient temperature for experiments in rats: a new method for determining the zone of thermal neutrality. J Appl Physiol 92:2667-2679.

Schäfer MK, Varoqui H, Defamie N, Weihe E, Erickson JD (2002) Molecular cloning and functional identification of mouse vesicular glutamate transporter 3 and its expression in subsets of novel excitatory neurons. J Biol Chem 277:50734-50748.

Smith BN, Banfield BW, Smeraski CA, Wilcox CL, Dudek FE, Enquist LW, Pickard GE (2000) Pseudorabies virus expressing enhanced green fluorescent protein: A tool for in vitro electrophysiological analysis of transsynaptically labeled neurons in identified central nervous system circuits. Proc Natl Acad Sci U S A 97:9264-9269.

Tanaka M, McKinley MJ, McAllen RM (2009) Roles of two preoptic cell groups in tonic and febrile control of rat tail sympathetic fibers. Am J Physiol Regul Integr Comp Physiol 296:R1248-R1257.

Tanaka M, McKinley MJ, McAllen RM (2011) Preoptic-raphe connections for thermoregulatory vasomotor control. J Neurosci 31:5078-5088.

Tsuchiya H, Oka T, Nakamura K, Ichikawa A, Saper CB, Sugimoto Y (2008) Prostaglandin E2 attenuates preoptic expression of GABAA receptors via EP3 receptors. J Biol Chem 283:11064-11071.

Usdin TB, Hoare SR, Wang T, Mezey E, Kowalak JA (1999a) TIP39: a new neuropeptide and PTH2-receptor agonist from hypothalamus. Nat Neurosci 2:941-943.

Usdin TB, Hilton J, Vertesi T, Harta G, Segre G, Mezey E (1999b) Distribution of the parathyroid hormone 2 receptor in rat: immunolocalization reveals expression by several endocrine cells. Endocrinology 140:3363-3371.

Usdin TB, Bonner TI, Hoare SR (2002) The parathyroid hormone 2 (PTH2) receptor. Receptors Channels 8:211-218.

Varoqui H, Schäfer MK, Zhu H, Weihe E, Erickson JD (2002) Identification of the differentiation-associated $\mathrm{Na}+/ \mathrm{PI}$ transporter as a novel vesicular glutamate transporter expressed in a distinct set of glutamatergic synapses. J Neurosci 22:142-155.

Voss-Andreae A, Murphy JG, Ellacott KL, Stuart RC, Nillni EA, Cone RD, Fan W (2007) Role of the central melanocortin circuitry in adaptive thermogenesis of brown adipose tissue. Endocrinology 148:1550-1560.

Ward HL, Small CJ, Murphy KG, Kennedy AR, Ghatei MA, Bloom SR (2001) The actions of tuberoinfundibular peptide on the hypothalamo-pituitary axes. Endocrinology 142:3451-3456.

Yoshida K, Nakamura K, Matsumura K, Kanosue K, König M, Thiel HJ, Boldogköi Z, Toth I, Roth J, Gerstberger R, Hübschle T (2003) Neurons of the rat preoptic area and the raphe pallidus nucleus innervating the brown adipose tissue express the prostaglandin E receptor subtype EP3. Eur J Neurosci 18:1848-1860.

Yoshida K, Li X, Cano G, Lazarus M, Saper CB (2009) Parallel preoptic pathways for thermoregulation. J Neurosci 29:11954-11964.

Yoshimatsu H, Egawa M, Bray GA (1993) Sympathetic nerve activity after discrete hypothalamic injections of L-glutamate. Brain Res 601:121-128.

Zaretskaia MV, Zaretsky DV, Shekhar A, DiMicco JA (2002) Chemical stimulation of the dorsomedial hypothalamus evokes non-shivering thermogenesis in anesthetized rats. Brain Res 928:113-125.

Zylan KD, Carlisle HJ (1992) Effect of ambient temperature on the paradoxical metabolic responses to norepinephrine. Pharmacol Biochem Behav 43:577-582. 